\title{
ASTURIAS 1898-1914. EL FINAL DE UN CAMPESINADO AMABLE${ }^{1}$.
}

\author{
por \\ JORGE URÍA \\ Universidad de Oviedo
}

RESUMEN: Frente a la imagen combativa e insurreccional del campesino sin tierra del sur español, durante la Restauración se iba a codificar un contramodelo del pequeño propietario del norte atlántico, de corte pacífico, conservador y conformista. Contribuyó a ello todo un conjunto de investigaciones jurídicas, históricas o folclóricas, además de una literatura donde la obra de Palacio Valdés destaca por muchas razones. La imagen de la Asturias retratada por este autor -coincidente con otras similares del País Vasco, Santander o Galicia-obedecía en parte a una realidad donde subsistía la pequeña propiedad o ciertas tradiciones interpretadas como "patriarcales", $y$ en donde además la mercantilización de productos como los ganaderos habian permitido capitalizar las explotaciones agrarias haciéndolas viables y más rentables. Esa imagen «patriarcal» del campo, sin embargo, era una entera falsificación; lo que es más el campesino, pese a que siguió recurriendo en ocasiones a formas comunitarias o de acción colectiva de aspecto atrasado y tradicional, las usaba para defenderse y reubicarse en un mundo crecientemente penetrado por unas relaciones de producción capitalistas que generaban nuevos conflictos en torno a la propiedad de la tierra, o a la mercantilización de algunos productos agrícolas o ganaderos.

Palabras Clave: Asturias. Campesinado. Historia contemporánea.

ABSTRACT: In contrast with the combative and insurrectionary model of the landless peasant in the south of Spain, a counter-model was developed in the Atlantic coast, an image of the peaceful, conservative and conformist small landholder. A variety of legal, bistorical and folkloric elements contributed to the forging of this image, in addition to literary sources in which the work of Palacio Valdés stands out for a

1 El contenido de este artículo fué adelantado en el Annual Meeting of The Society for Spanish and Portuguese Historical Studies (New York, 2000). Abstract: URIA, J.: "Asturias 18981914. The End of a Friendly Peasantry", Society for Spanish and Portuguese Historical Studies. Bulletin, vol XXV, I (2000), pp. 31-32. 
variety of reasons. The image od Asturias despicted by this author -coinciding with similar portrayal of the Basque Country, Santander and Galicia-, in part reflected the social reality of small property-bolding and "patriarchal» traditions. The commercialisation of this economy had made agrarian holdings more viable and profitable. However, the patriarchal image of the countryside was entirely false. The peasant, despite resorting occasionally to very traditional forms of community and collective action, sought to defend and relocate bimself in a world increasingly penetrated by capitalist relations of production that generated new conflict over land.

KEY WORDS: Asturias. Peasantry. Contemporary history.

«Afable, complaciente, afectuoso»; tal es la definición del diccionario de la Real Academia Española de lo amable. El término, por tanto, se vincula nítidamente a connotaciones positivas que amplían y profundizan su sentido etimológico, que le relaciona con lo digno de ser amado (amabilis) el amor mismo, o el sentimiento - de tanta amplitud en la lengua latina - de la amistad ${ }^{2}$. Su asociación a la realidad del campesinado español de finales del siglo XIX y principios del XX, en consecuencia, puede parecer una audacia a quien considere cuán distinta era su estimación en el periodismo y la publicística de la época.

La época de la Restauración española, en efecto, percibe al campesinado como un problema agudizado a raíz de sucesos como los asesinatos de la «La Mano Negra» que abrieron, como es sabido, una campaña propagandística que asociaba todo tipo de crímenes al anarquismo andaluz y, por ende, a los ambientes rurales en donde habían arraigado. Desde las últimas décadas del siglo XIX, por tanto, se afianza una imagen inquietante del trabajador de la tierra, y la sospecha de que tras su miseria había una amenaza de desestabilización. En los años ochenta y noventa, en consecuencia, se identificaba al proletariado agrícola andaluz con el anarquismo y con una cultura de la violencia que salpicaba sus manifestaciones reivindicativas. A finales de siglo ya se había desarrollado, incluso, una cobertura "científica» de esa identificación criminalizando al anarquismo gracias a la moderna «ciencia penal» o a la sociología del crimen ${ }^{3}$.

2 Real Academia Española, Diccionario de la Lengua Española, Madrid, 1984, tomo I, COROMINAS, J.: Breve diccionario etimológico de la lengua castellana. Madrid, 1973.

3 Sobre la "Mano Negra», véanse las aportaciones clásicas de DíAz DEL MORAL (Historia de las agitaciones campesinas andaluzas, Madrid, $1^{a}$ ed. de 1929), GARCía VENERO, M. (Historia de las Internacionales en España, Madrid, desde 1954; Historia de los movimientos sindicalistas españoles, Madrid, 1961), Fernández Almagro, M.: Historia del reinado de Alfonso XIII, Barcelona, 1936), LidA, Clara E. («Agrarian Anarchism in Andalusia; Documents on the Mano Negra», International Review of Social History, V, XIX, 1969).Un buen ejemplo del seguimiento periodístico de este asunto -con todos los tópicos y limitaciones que le son inherentes- es el de los artículos que le dedicó en los años ochenta el catedrático y novelista Leopoldo Alas; véase sobre el particular el estudio de LISSORGES, Y. (Clarín político, v. I, Barcelona, 1980, v. I, pp. 46-47 y 340 y ss.) o el de LIDA, Clara E. (Antecedentes y desarrollo del movimiento obrero español (1835-1888), Madrid, 1973, p. 444 y ss.). Sobre 
Dado el predominio que ha tenido dentro de la historiografía española una historia social íntimamente asociada al "movimiento obrero", y a la historia externa de las organizaciones políticas o sindicales, de sus líderes y sus grandes acciones reivindicativas, no es extraño que en la imagen histórica del campesinado hayan dominado los aspectos que mejor evidenciaban su encuadramiento sindical o su disposición para las llamativas acciones colectivas ${ }^{4}$. El campesinado sin tierra del sur de España contaminado de anarquismo fue, por tanto, su protagonista; y esa imagen, tan poderosa en la época histórica en la que surge, tendió a adueñarse de la historiografía soslayando hasta cierto punto el hecho de que, a su lado, la publicística decimonónica o el mundo de la creación literaria habían ido codificando su contramodelo. Se trataba del pequeño campesino propietario o arrendatario del norte de España, vinculado desde el principio a imágenes positivas de armonía social; de cierto bienestar en el capítulo del consumo, o incluso de asociación a una mítica y dichosa «democracia concejil», que hacía de la asamblea de vecinos un organismo nuclear de la organización de su vida cotidiana y que permitía unos aceptables grados de autogobierno. Ese va a ser el protagonista de estas páginas y en él habremos de centrarnos ahora.

\section{LA «ESPAÑA HÚMEDA» Y LA IDEALIZACIÓN DEL CAMPESINADO.}

La visión idealizada de la comunidad campesina del Norte de la Península Ibérica aparece bien descrita, por ejemplo, en el País Vasco. Desde los siglos $\mathrm{XV}$, XVI y XVII, se definen un conjunto de tópicos historiográficos sobre un mundo agrario asociado a mitos como el de la «hidalguía universal» - y por tanto que extiende a la totalidad de la población los privilegios estamentales nobiliarios-, y al «igualitarismo vasco»; y que se vincula inequívocamente a una mentalidad arcaizante que solía conectar con el tradicionalismo político y la nostalgia por la situación del Antiguo Régimen. Ese substrato pasará a la literatura fuerista explayandose en una visión de un País Vasco tradicional y

el desarrollo de la criminología finisecular, vid. TRINIDAD FERNÁNDEZ, P.: La defensa de la sociedad. Cárcel y delincuencia en España (siglos XVIII-XX), Madrid, 1991. Sobre el análisis sociológico acerca del anarquismo en los mismos años, véase URía, J.: «Posada, el Grupo de Oviedo y la percepción del conflicto social», en URíA, J. (Coord.), Institucionismo y reforma social en España, Madrid, 2000, pp. 131 y ss. Véase también el trabajo de BREY, G. y ForGUES, R.: «Algunas rebeliones campesinas en la literatura española: Mano Negra, Jerez, Casas Viejas y Yeste», en TUÑón DE LARA, M. (et alii), La cuestión agraria en la España Contemporánea, Madrid, 1976, pp. 329-361.

4 Sobre el dominio de estas perspectivas en la historiografía española resulta ya clásica la aportación de Álvarez JunCO, J. y PÉrez Ledesma, M.: «Historia del movimiento obrero. ¿Una segunda ruptura?», Revista de Occidente, 12 (1982). El punto de vista conflictual y el predominio de la perspectiva de la clase en estos análisis, en detrimento de otras dimensiones del análisis social —como la del género, la comunidad local, los niveles institucionales y simbólicos, etc.- es un aspecto en el que incide la excelente introducción del estudio de Pamela Beth Radcliff, From mobilization to civil war. The politics of polarization in the Spanish city of Gijón, 1900-1937, New York, 1996, esp. pp. 7 y ss.

Hispania, LXII/3, núm. 212 (2002) 1059-1098 
campesino, descrito como un lugar idílico antes de la llegada de la industrialización. En el arranque del liberalismo, por otra parte, el País Vasco llegó a encarnar el ideal doctrinario de una sociedad conservadora y sin demasiados conflictos sociales que la convirtió, al decir de Juaristi, en la «utopía de la España conservadora»s.

La «hidalguía universal», en realidad, se defendía también en otros lugares de la España atlántica como Asturias y Cantabria. La generalización del estatus de nobleza justificaba aquí también tanto privilegios fiscales, como la participación en la burocracia de la monarquía; entrandose, por tanto, en competencia con una pequeña hidalguía vasca de letrados que basaban en idénticos argumentos su presencia en la administración del Estado. Como J. Juaristi mostró en su día, la creencia en unos orígenes de España que partían del asentamiento en la zona vasco-cantábrica de Tubal, nieto de Noé, proporcionó una coartada operativa a la burocracia vizcaína del siglo XVI frente a la competencia de los santanderinos o de los escribanos judíos. La argumentación sobre la limpieza de sangre y la «pureza» de los vizcaínos, con todo, se esgrimió también por la hidalguía santanderina o la asturiana adquiriendo así la literatura tubalista un desarrollo no desdeñable en estas últimas zonas. La publicación de La Cantabria del Padre E. Flórez ( ${ }^{\mathrm{a}}$ ed. de 1768 ) suponía en este sentido uno de los postreros intentos de refutación por parte de los santanderinos de las pretensiones del monopolio vasco de la hidalguía universal y la pureza de sangre y de los beneficios que de ello se derivaban. La obra de autores asturianos como Tirso de Avilés en el siglo XVI, de Luis Alfonso de Carballo en el siglo XVII, o de M. M. Trelles Villademoros en el XVIII, redundaban también en idénticas tesis ${ }^{6}$.

Ese conjunto de escritos afianzó una literatura mitificadora de las virtudes y cualidades de estas regiones y de sus naturales, pero la argumentación histórica no constituyó la única vía para tejer esta visión fabulada del norte atlántico peninsular. Basándose en las recopilaciones de costumbres jurídicas que testimoniaban pretendidamente la cohesión comunitaria aldeana, o su íntima armonía como colectivo sin sustanciales diferenciaciones económicas o de intere-

5 Jon JUARISTI es autor del que quizá sea el estudio más clarificador acerca de la «invención de la tradición» vasca y, en concreto, de El linaje de Aitor (Madrid, 1987; esp. pp. 23 y ss.).Conviene completar su lectura con el excelente libro de ELORZA, A.: Ideologías del nacionalismo vasco (San Sebastián, 1978). Una solvente y actualizada visión del nacionalismo vasco en J. L. de la Granja, El nacionalismo vasco. Un siglo de bistoria, Madrid, 1995.

6 JuARISTI, J.: Vestigios de Babel. Para una arqueología de los nacionalismos españoles, Madrid, 1993, pp. 3-25. SUÁREZ CORTINA, M.: Casonas, bidalgos y linajes. La invención de la tradición cántabra. Santander, 1994, pp. 11 y ss.; URÍA, J.: «Sobre historia e historiografía en la Edad Contemporánea asturiana», Bulletin d'Histoire Contemporaine de l'Espagne, 20 (1994), pp. 267 y ss.; la justificación de los privilegios estamentales de los asturianos, lejos de apoyarse únicamente en tesis goticistas, se sustentaban también en el tubalismo, como se demuestra en la historiografía asturiana del siglo XVI, XVII y XVIII. 
ses, se iba a llegar a una visión igualmente grata del mundo campesino; aunque esta vez su área geográfica de aplicación abarcase un espacio mayor, que incluía a Galicia, y otros lugares del centro o de la periferia peninsular. La obra de Alfredo García Ramos es buen ejemplo de ello; sus estudios de principios de siglo XX sobre las prácticas consuetudinarias gallegas, y en donde se entrecruzan los enfoques propios de la Escuela Histórica del Derecho y el Catolicismo Social, constituyen un reconocido ejemplo de visión armónica del mundo rural. En ese contexto se sitúa, asimismo, su concepción de la familia como una unidad social capaz de preservar a lo largo del tiempo su patrimonio, y asociada al tipo ideal del pequeño campesino propietario, o la minusvaloración de los conflictos entre propietarios y aparceros. El relieve otorgado a la cohesión comunitaria aldeana traducido en la pervivencia de la propiedad o de los usos colectivos de la tierra, entretanto, puede testimoniarse en trabajos de juristas gallegos del siglo XIX como Castro Bolaño mucho más que en autores como García Ramos, poco atento a este tipo de desarrollos?

$\mathrm{Su}$ parentesco con visiones de la historia del derecho español como la de Joaquín Costa es evidente pese a las distancias ideológicas entre unos y otros, testimoniando su preocupación por el colectivismo agrario un entusiasmo palpable por una supuesta democracia igualitaria popular, que liga al autor con un substrato ideológico de raigambre liberal y mitificador de una especie de democracia primigenia española; y cuya evidencia podía ser tanto la mítica visión de las Cortes medievales españolas como institución "democrática», cuanto la supervivencia de las prácticas colectivas estudiadas por Costa, o la existencia de un substrato de "derecho popular» sobre el que se indaga con particular insistencia desde finales del siglo XIX. La publicación desde 1898 por parte de la Real Academia de Ciencias Morales y Políticas de las primeras entregas sobre Derecho Consuetudinario y Economía Popular, como resultado de diversos concursos públicos abiertos al efecto, encaja en estos patrones; al igual que la conocida compilación de trabajos conducida por el propio Costa en Derecho consuetudinario y Economía popular de España, o la Historia de la propiedad comunal de Rafael Altamira, basada en su tesis doctoral dirigida por un Gumersindo de Azcárate, que prologa la obra ${ }^{8}$.

7 CARDESín DíAZ, J. $\mathbf{M}^{\mathrm{a}}$.: «Entre el regionalismo jurídico y el catolicismo social: El derecho consuetudinario en Alfredo García Ramos (1908-1910)", en Galicia e a Historiografía, Santiago, 1993. Del mismo autor, Tierra, Trabajo y reproducción social en un aldea gallega (S. XVIII-XX): Muerte de unos, vida de otros, Madrid, 1992, pp. 175-177 y 188-190.

8 Sobre el parentesco de Costa con tesis como las defendidas por Castro Bolaño vid. CARDESíN, J. Ma .: Tierra, Trabajo... opus cit., pp. 189-190. Una alusión al papel de la Academia de Ciencias Morales y Políticas en cuanto a la Historia social española en URÍA, J.: «La historia social y el contemporaneísmo español. Las deudas del pasado", en SARASA, E. y SERRANO, E.: La Historia en el Horizonte del año 2000, Zaragoza, 1997, pp. 108-109. Sobre Costa resulta obligada la consulta de la reciente compilación de los trabajos de ORTí, A. en En torno a Costa, Madrid, 1996. Véase también Altamira, R.: Historia de la propiedad comunal, Madrid, 1890. Tanto Costa, como Altamira o Azcá- 
La idealización de los ambientes rurales del norte atlántico, por tanto, tenía antecedentes de cierta solidez académica. Nada más lógico, pues, que arraigasen en Asturias las imágenes encomiásticas de la familia rural, de la «democracia concejil» o de la vida campesina en general. En efecto, a principios de siglo un reputado penalista, Félix de Aramburu, valoraba positivamente las pervivencias en Asturias de una «sociedad familiar» entendida como colectividad armoniosa e igualitaria. Por supuesto, la subsistencia de «algunos usos e instituciones asturianas que constituyen manifestaciones residuales del régimen primitivo del suelo» eran comentadas con cierto detenimiento, haciéndose eco el catedrático de las alusiones a Asturias recogidas en el Colectivismo agrario en España de Costa. Este último, en realidad, había utilizado materiales recopilados por Manuel Pedregal, el conocido abogado y político republicano con el que había colaborado ya en obras como su Derecho consuetudinario..., o los Materiales para el Derecho municipal consuetudinario, redactado tambíen con Serrano y G. De Linares. Desde una órbita política diametralmente opuesta, también defendía el tradicionalista Vizconde de Campogrande la integridad de un «Derecho municipal» en Asturias con arreglo al que se seguían rigiendo los vecinos «manteniendo su autoridad en frente de la ley», así como la viabilidad de un trabajo corporativo indicador de la cohesión y voluntad de ayuda mutua entre los asturianos de las zonas rurales. En fin, al igual que en Galicia, también en Asturias la mitificación de la familia, en tanto que unidad de explotación rural, tuvo sus panegiristas. El trabajo de Ramón Prieto Bances sobre «La casería asturiana», ya en los años cuarenta del siglo XX, hay que entenderlo como la coronación de una línea anterior de preocupación por la "propiedad familiar» - presente también en la obra del Vizconde de Campo Grande- y que se salvaguardaba, precisamente, a través de la figura de la casería; que agrupando al conjunto de bienes que configuraban la explotación rural familiar, había sabido prolongar su vigencia histórica gracias a la ayuda del trabajo colectivo familiar o comunitario, y a las benévolas condiciones de los arrendamientos ${ }^{9}$.

rate, adelantaron sus preocupaciones en este terreno en sus artículos del Boletín de la Institución Libre de Enseñanza; véase en esta publicación la colaboración de COSTA, J.: «Plan de un trabajo sobre el Derecho Consuetudinario», t.XI (1887), las de AZCÁrATE, G. de: «Historia del derecho de propiedad», t. II (1878) y t. III (1879); «La propiedad colectiva del suelo en diferentes países», t. X (1886); y «Vestigios del primitivo comunismo en España», t. VII (1883), o la de ALTAMIRA, R. («La propiedad comunal en la época del feudalismo», t. XII (1888). El interés por el «comunismo agrario" y su vinculación con el estallido de la «cuestión social» en los años ochenta del siglo XIX, es expuesta con toda claridad en los artículos citados de Azcárate; también en la obra de PEDREGAL, M.: «Apuntes sobre el derecho de propiedad, t. VIII (1884)

9 Aramburu y Zuloaga, F. de: Monografía de Asturias, Oviedo, 1899 (ed. facs. Gijón, 1989, pp. 90-91). Una biografía sucinta de Pedregal en SuÁreZ, C.: Escritores y Artistas asturianos, Oviedo, 1957, tomo VI, pp. 76-85. Campo Grande, Vizconde de, Alonso, Ceferino, GonZÁlez, J.: Doctrina asturianista aprobada por la Junta regionalista del principado, Oviedo, 1918 (ed. fasc. Gijón, 1977), vid. esp. pp. 31 y ss. dedicadas a «El Derecho asturiano»; el vizconde, como ya podrá suponerse, era un nostálgico de las instituciones del Antiguo Régimen, según se observa entre otras

Hispania, LXII/3, núm. 212 (2002) 1059-1098 
La visión positiva del norte peninsular, en todo caso, tenía cierta base; su situación social, de hecho, era mejor que la del proletariado agrícola del sur en varios sentidos. Los beneficios objetivos de la peculiar autonomía administrativa vasca conllevaron, por ejemplo, una menor presión impositiva o la exención del servicio militar; su sistema de aduanas, además, gravaba los productos no en los puertos de mar, sino al salir las mercancías hacia Castilla; creandose un área de consumo a más bajo precio de productos como los cereales, el bacalao o los tejidos, sin por ello perder las ventajas de exportación de productos competitivos como el hierro en barras. Todo ello contribuyó a la viabilidad económica del caserío vasco, unidad de explotación campesina en la que se equilibraban los aprovechamientos agrícolas y ganaderos o los beneficios de los montes comunales y que, en el tránsito del siglo XIX al XX, estaba girando hacia una mercantilización creciente de sus producciones gracias, esencialmente, a su progresiva orientación ganadera ${ }^{10}$.

También en la zona santanderina puede detectarse la existencia de un campesinado cuya consolidación en el período intersecular es indudable; en este caso se producirá una expansión de la pequeña explotación y la pequeña propiedad. Aunque la propiedad agraria podía concentrarse en pocas manos, ello no eliminaba la existencia de una generalizada difusión de exiguas propiedades entre numerosos campesinos que se verán obligados, de este modo, a complementar sus ingresos recurriendo al arrendamiento y la aparcería. De todos modos el espacio de cultivo integrado por campos labrados y prados supondrá

cosas en su trabajo de Doctorado, leído en 1909, sobre la Junta General del Principado, una cámara corporativa regional con atribuciones administrativas amplias disuelta a la llegada del liberalismo, y que era definida por el autor como un tipo preclaro de las «instituciones y organismos basados en la naturaleza misma del país»; vid. su reedición en CAveda y NAVA, J., Villa, M. de la, CAMPO GRANDE, Vizconde de: La Junta General del Principado, Gijón, 1989, p. 105. La entidad que le atribuye este último autor al "Derecho asturiano", en todo caso, es discutida en obras como la de TUERo Bertrand, F.: Instituciones Tradicionales en Asturias, Salinas (Asturias), 1976. M. Pedregal, en todo caso, ofrecería en sus "Apuntes sobre el derecho de propiedad» (Boletín de la Institución Libre de Enseñanza, t. VIII (1884) esp. pp. 225-30) abundantes datos sobre la pervivencia de una «democracia concejil» idealizada en comarcas como Cangas de Tineo, Proaza, Aller o Caso. Sobre las virtudes de la familia como entidad preservadora del patrimonio vid. PRIETO BANCES, R.: «La casería asturiana», en Obra escrita, Oviedo, 1976, tomo I, pp. 420-454; las mismas tesis de fondo se contienen en Pedregal, M.: "La familia rural en Asturias», en Boletín de la Institución Libre de Enseñanza, t. XXIII (1899), p. 20.

10 JuARISTI, El linaje..., opus cit., p. 29. CORCUERA ATIENZA, Javier: Orígenes, ideología y organización del nacionalismo vasco (1876-1904), Madrid, 1979, pp. 12-38. ETXEZARRETA, Miren: El Caserío Vasco, Bilbao, 1977. Para una caracterización más precisa de la evolución económica del País Vasco, vid. FERNÁNDEZ DE PINEDO, E.: Crecimiento económico y transformaciones sociales en el País Vasco, Madrid, 1974. El reciente trabajo de KURLANSKY, M.: Cod. A Biography of the Fish That Changed the World (New York, 1998), añade numerosas precisiones sobre el papel del bacalao en la vida cotidiana, la historia y la cultura vasca; aunque tal vez sea demasiado crédulo acerca del «enigmático» pueblo vasco y de su capacidad para «conservar» su «independencia». Se insiste en las mismas ideas en su todavía más reciente libro, The basque History of the World (New York, 1999). 
siempre poco, tal y como subraya J. Ortega Valcárcel, en relación con la superficie dedicada a los montes, que se configuran como una inmensa reserva de explotación; los comunales, de este modo, facilitarán unos usos ganaderos que estarán en los mismos cimientos de la explotación campesina, al tiempo que servirán como base a partir de los años treinta del siglo XIX para la consolidación de la pequeña propiedad a partir de una usurpación de los terrenos comunes legalizada a posteriori. Este último proceso se prolongará a lo largo de todo el siglo XIX y la primera mitad del siguiente. Los pequeños propietarios santanderinos, pese a lo escueto de su propiedad inicial, configurarán en todo caso unidades de cultivo viables gracias al giro hacia una explotación familiar intensiva de tipo lechero'11.

Quizá sea el caso de Galicia, con todo, el de mayor complejidad dentro de los del conjunto de la España atlántica. En un reciente trabajo R. Soutelo incide en el protagonismo que en este caso tienen unas explotaciones domésticas de variada tipología en las que ni «desaparece la pequeña propiedad ni se produce una proletarización que convierta al salario en recurso fundamental del campesinado norteño", imponiéndose en cambio situaciones muy variables que mezclan la condición «de jornalero a tiempo parcial o estacional, propietario insuficiente, arrendatario y aparcero». De hecho, el punto de vista que no limita a la propiedad plena del suelo o al grado de salarización los patrones de medida de la situación campesina, se comparte cada vez más entre los especialistas. El interés por las formas de organización familiar y sus estrategias es un buen ejemplo de la diversificación temática o conceptual que se está produciendo desde los años ochenta y noventa en este terreno, así como la convergencia de perspectivas metodológicas variadas como la historia local, la antropología social o la historia rural. En el modélico estudio sobre San Martiño do Castro hecho por J. María Cardesín se incidirá, en este sentido, en el carácter simplificador que suele tener el término de "patrimonio" campesino, y en la incapacidad que muestran conceptos como el de «propiedad privada» para desentrañar el conjunto complejo de derechos sobre la tierra que caracterizaban el mundo agrario antes y después del s. XIX. Las complejas formas contractuales de «arrendamiento» o de «aparcería», o las redes familiares o clientelares pueden establecer, de hecho, una trama diversificada e informal, pero eficaz, de aprovechamientos de recursos agrarios ajenos o colectivos que puede tener más importancia que la propiedad del suelo. En idéntico sentido la propiedad de los ganados se convierte en un indicador sensiblemente más preciso de la capacidad económica del campesinado. El que no se acceda a la propiedad, por tanto, o la misma supervivencia del viejo universo ideológico tradicional y de prácticas

11 ORTEGA VALCÁRCEL, José: «La consolidación de la pequeña explotación agraria en Cantabria: de campesinos renteros a propietarios en precario", en SAAVEDRA, P. y VILLARES, R, eds.: Señores y campesinos en la Península Ibérica, siglos XVIII-XX, Barcelona, 1991, pp. 156-172. Coincide con estas tesis el artículo de SÁNCHEZ GómEZ, M. A.: "Transformaciones agrarias en Cantabria, 1800-1931», en SUÁrez CortinA, M., ed., El perfil de «La Montaña», Santander, 1993, pp. 149-151. 
comunitarias «atrasadas», no tienen por qué interpretarse como indicios de rutina o de rezagamiento en el proceso de inserción en el capitalismo de estas comunidades. La persistencia de una propiedad o gestión colectiva de ciertos recursos, los mecanismos de ayuda o de sociabilidad intensamente comunitaria que se advierten en el área gallega todavía a principios del siglo XX pueden suponer, por el contrario, y en contra de los paradigmas habituales de modernización, una simple adaptación al mercado que puede ser más eficaz dentro de esos mismos marcos comunitarios ${ }^{12}$. No se puede obviar, es cierto, la situación de desigualdad y privilegios que podía subsistir dentro de estas comunidades de campesinos; la capacidad de maniobra de las élites locales o municipales, o de algunos propietarios; e incluso el papel tradicionalmente jugado en todo el norte español por la emigración hacia América como aliviadero de la sobrepoblación y las tensiones sociales a las que se asociaba. Pero, al mismo tiempo, también es un hecho que los campesinos de la España atlántica, por encima de la enorme variedad de situaciones en que podían estar inmersos, podían gozar de una situación mejor que la de un jornalero andaluz o un yuntero extremeño. Todo ello rodeaba de un aura de verosimilitud el ciclo de literatura ruralista que magnificaba las cualidades amables de la vida en el campo, haciéndose la ficción literaria mucho más eficaz y creíble.

Aunque nuestro examen va a centrarse en el caso de una sola región -la asturiana-, conviene no olvidar que el desarrollo de este singular corpus narrativo afectó a otros espacios geográficos y que, por supuesto, se plasmó en formatos literarios diversos y en muy variadas y hasta opuestas orientaciones ideológicas. Parte de la literatura fuerista vasca encajó en estos supuestos cuando recurría al ruralismo y al costumbrismo para embellecer la imagen campesina de un País Vasco tradicional. Algunos relatos de Antonio Trueba figuran entre lo más conocido de este conjunto literario; pero el autor coincide con otros en un mismo corpus ideológico que opone la ruralidad armónica de las virtudes genuinas vascas a los ambientes industriales; se trata de una pugna entre los valores del campesino - el vasco por antonomasia- y el emigrante español o maqueto, que invade este viejo mundo para corromper sus costumbres y quebrar su viejo equilibrio. Este esquema argumental, con antecedentes en la

12 Soutelo VÁzQuez, Raúl: «Algunas estrategias reproductivas de las familias campesinas en la Galicia rural. Los grupos domésticos de 'Caseiros' en Orense, 1880-1960», en Sociología del Trabajo, 33 (1998), p.131. FERNÁNEZ CORTIZO, C.: «Estrategias familiares y pequeña explotación campesina en la Galicia del siglo XVIII", en SAAvedra, P. y VIllares, R.: opus cit., p. 310 y ss.. CARDEsín, J. María: Tierra... opus cit., esp. pp. 142, 181-187, 175 y ss., 201, 232 y ss.. Del mismo autor, «Repensando el Caciquismo: espacio político y agencia social en la Galicia de la Restauración» (en Historia y Critíca, II (1992), pp. 191 y ss.), y «El mito d e la comunidad campesina: ¿Crisis de un agente social, o crisis de un concepto dentro de las ciencias sociales?», en Concepcións espaciais e extratexias territoriales na historia de Galicia, Santiago de Compostela, 1993. BAR VICENTE, Ma Jesús: «Reconsiderando la persistencia del régimen foral en la Galicia del siglo XIX: Una «racionalidad de otro orden»«, en Agricultura y Sociedad, 70 (1994). 
novela histórica fuerista isabelina, es el nervio de obras de los años noventa del siglo XIX como la zarzuela De Vizcaya a Vizkaia, del sacerdote Resurrección María de Azkue, y se repite en la comedia antimaqueta De fuera vendrá... del propio Sabino Arana o, siempre sin salirse de la última década del siglo, en la novela de Arturo Campión Blancos y negros. Guerra en la paz. Antes de iniciarse la Guerra europea, y en un clima de nacionalismo cultural bien perfilado, aún se publicarían entre algunos otros títulos de este costumbrismo nostálgico, las novelas del sacerdote Domingo de Aguirre sobre la vida de los pescadores ( $E l$ salitre) o los pastores vascos (El helecho); obras de J. M. Echeita como Josetxo o La patria amada, o comedias del abogado Nicolás Viar como Alma Vasca ${ }^{13}$.

Prescindiendo ahora de las notas marcadamente nacionalistas y xenófobas de este tipo de literatura, no ha dejado de señalarse su parentesco con los esquemas novelísticos del santanderino José María de Pereda ${ }^{14}$. El autor, y sobre todo su novela Peñas arriba, pasa por ser uno de los arquetipos más conseguidos de idilio rural en un escenario campesino idealizado y socialmente armónico. En este universo rural la figura del patriarca sobresale por sus cualidades de gestor eficaz y su conocimiento de métodos de cultivo modernos. El cuidado de su patrimonio no le impide, sin embargo, convertirse en un referente moral para la comunidad, además de oficiar como incitador a la difusión de nuevos métodos de cultivo - la introducción de la remolacha azucarera, por ejemplo, o el abandono del labrado conjunto de los campos comunales-. Ninguno de estos comportamientos «modernos», sin embargo, entrará en contradicción con la verdadera sustancia del universo tradicional en el que se inserta; su intención será, más bien, adaptar a los tiempos ese substrato heredado que no se discute y del que el patriarca es su principal abanderado; defendiendo las tradiciones del pueblo donde reside, y cuyo universo opone al progreso industrializador y técnico con su poder disolvente de lo tradicional. En la obra de Pereda, en fin, podemos encontrar la oposición entre la naturaleza del campo y la artificiosi-

13 Para una contextualización de este corpus literario dentro del nacionalismo vasco, vid. GrANJA, J. L. de la: opus cit.. El ciclo de la literatura fuerista de tipo histórico-legendario, es analizado rigurosa y sugerentemente en JUARISTI, J.: El linaje..., opus cit.. Al ruralismo de la literatura vasca de la época alude ESTORNES ZUVIZARRETA, Idoia, en "Educación, prensa y cultura», en la obra de varios autores Los nacionalistas. Historia del nacionalismo vasco. 1876-1960, Vitoria, 1995, pp. 255 259. Una visión general de la literatura vasca vinculada al nacionalismo en JUARISTI, J.: «La cultura vasca», en La Edad de Plata de la cultura española (1898-1936). Vol II. Letras. Ciencia. Arte. Sociedad y Culturas, Tomo XXXIX de la Historia de España Menéndez Pidal, dirigida por Jover ZAMORA, pp. 927 y ss.. Una visión contrapuesta a la de Juaristi, y sensiblemente más benévola con esta literatura nacionalista, por ejemplo, en MENIKA LARRINAGA, Igone: «Literatura», en la obra de varios autores País Vasco. Vizkaia, Madrid, 1993, pp. 188 y ss. Véanse también sobre estas cuestiones ViLLASARTE, Luis: Historia de la literatura vasca, Burgos, 1979; o SARASOLA, Iban: Historia social de la literatura vasca, Madrid, 1987.

14 Miguel de UnAmuno, cuando reseña la novela citada de Campión, subrayará su dependencia de los modelos de la novela regional de Pereda, según hace notar JUARISTI, J. en «La cultura...», opus cit. p. 929.

Hispania, LXII/3, núm. 212 (2002) 1059-1098 
dad de la ciudad hasta defenderse una vuelta a lo rural compartida por la literatura del momento; la de Tolstoy, Dostoievski en parte, Julio Dinis o Eça de Queiroz. Pero lo que más nos importa ahora es la vertiente de la obra de Pereda como retrato social del mundo campesino de la Montaña santanderina; ese mundo de propiedad más repartida, de prósperos arrendatarios y aparceros, de pocos obreros agrícolas y escasez de gran propiedad, o de escasa violencia social y criminalidad. En realidad, pocos universos de ficción literaria pueden ser más explícitos. La idealización del comunitarismo igualitario de las aldeas norteñas es diáfana, tal y como ha subrayado Jean Le Bouill; Tudanca, el pueblo retratado en Peñas arriba, en donde se reflejan las prácticas comunitarias conservadas en las antiguas ordenanzas concejiles, había sido objeto ya de atención tiempo antes por parte de la literatura jurídica preocupada por el colectivismo agrario. En los años ochenta, en efecto, G. González de Linares había retratado la aldea como un ejemplo de «institución socialista»; en 1902, en Derecho consuetudinario y economía popular defendería de modo igualmente explícito unos aprovechamientos comunales que, según sus palabras, «aseguraban a las familias contra los reveses de la fortuna, manteniendo en lo posible el equilibrio y la armonía (dentro de los grados naturales) entre las diversas clases sociales». El mismo Pereda llegó a comparar con ventaja el estado saludable del campesinado montañés, con la miseria del campesinado del sur «sin más propiedad que un mezquino salario que le da el potentado» ${ }^{15}$.

\section{ASTURIAS: LA CREACIÓN LITERARIA DEL CAMPESINADO AMABLE}

Además de la literatura jurídica preocupada por el estudio del derecho consuetudinario, que ya conocemos, la idealización del campesinado y del universo rural asturiano constituyó un sentimiento ampliamente compartido tanto en la creación literaria, cuanto en las artes plásticas - y singularmente en la pinturao en una producción folclórica interesante, aunque necesitada de muchas caute-

is Sobre la obra de Pereda véase Fernández Cordero y Azorín, C.: La sociedad española del siglo XIX en la obra literaria de D. José $M^{a}$ de Pereda, Santander, 1970, esp. pp. 153-155, 275-279, y 291-30. El papel de Pereda como promotor de la cultura tradicional de la Montaña santanderina, y de una verdadera «invención de la tradición» en este contexto, puede verse en SUÁrez CORTINA, M.: Casonas..., opus cit., pp. 24 y ss.. De la relativamente extensa e interesante obra de Jean LE BoulLl sobre Pereda, muy dispersa, hay que citar obligatoriamente su magnífico análisis en «El propietario ilustrado o patriarca en la obra de Pereda», en GARCía DeLGADO, J. L. (ed.) La cuestión agraria en la España Contemporánea, Madrid, 1976, pp. 311-328; de este artículo se toman los textos entrecomillados, que corresponden a la edición de 1902 de la obra compilada por Costa, y ya citada, sobre Derecho consuetudinario..., y a un artículo aparecido en La Abeja Montañesa de 22-X-1881. Sobre la difusión de las ideas de la «nueva fisocracia» en estos años véase la recensión de Adolfo BuYLla al libro de BOCCHIALINI El diritto alla terra, en la revista La Lectura, octubre (1902) pp. 212-214. Existen, como es lógico, excepciones a esta línea de idealización del mundo campesino; entre las más sobresalientes está, sin duda, la de la poetisa gallega Rosalía de Castro.

Hispania, LXII/3, núm. 212 (2002) 1059-1098 
las en su manejo. La mistificación de la realidad en la literatura folclórica era un hecho evidente, y si asomaba algo diferente al mundo inmóvil de una tradicionalidad mitificada, era casi siempre en medio de arranques de nostalgia o de denuestos hacia todas aquellas alteraciones que prostituían la pureza de lo antiguo. Ahora bien, si en el País Vasco se había procedido a una sistemática «invención de la tradición» en la búsqueda de una nación vasca superviviente en un ambiente campesino incontaminado, en Asturias se estaba procediendo a lo mismo, y con armas similares, para justificar la existencia de un «espíritu popular» español.

Puede tener bastante interés repasar, en esta perspectiva, los presupuestos ideológicos de la obra de Juan Menéndez Pidal; uno de los primeros y más destacados investigadores de las tradiciones en Asturias. Para el autor, el espíritu nacional español y la literatura popular eran mundos íntimamente trabados, y en el prólogo a su Poesía popular..., en medio de una prosa llena de arrebatos líricos, identificará la «poesía del pueblo» con «la representación genuina de las tendencias nacionales»; conservadas mejor que en cualquiera otra parte en los ambientes rurales, debido al atraso e inmovilidad que las caracterizaba. Para estos autores lo nacional iba impregnado de fuertes notas de «ahistoricidad»; el volksgeist hispano se había mantenido, casi desde siempre, como un denominador común a través de los cambios históricos y, por tanto, sus formulaciones más puras se hallaban donde menos se habían alterado por los cambios registrados a lo largo del tiempo. En el campo era por tanto donde, como decía Pidal, el observador «creerá hallarse aún en plena Edad Media» y podrá ver a «los vecinos congregados a campana tañida reunirse en concejo para tratar del procomún; y oirá resonar en las cañadas y en los valles canciones romancescas». Por consiguiente, aquel era el ambiente adecuado para rescatar la pura esencia de la patria, que pervivía allí "protestando contra la extinción del espíritu nacional y las virtudes caballerescas» ${ }^{16}$.

Los folcloristas, por tanto, tendieron a forjar una imagen del campo impregnada de nostalgia y de una carga ideológica reaccionaria. Algunos de los textos del folclorista Balbín de Unquera a propósito del contenido y virtudes de las coplas populares, y con inequívocos acentos de égloga clásica, constituían buenos ejemplos de estas tendencias. Para el folclorista era en los campos asturianos donde el amo concierta con sus criados las labores del siguiente día» en un clima tan armonioso como el de los «inocentes amores de los Pablos y Virginias de aldea y los diálogos de Salicios y Nemorosas que apacientan el ganado» ${ }^{17}$. La obra de Pidal coincidía en el tono, alcanzando niveles de paroxismo literario al evocar las noches pasadas «en la cabaña de bajas paredes y empinado techo de yerba, palacio del pastor que allí con la soledad vive feliz en

\footnotetext{
16 MENÉndez PIDAl, Juan: Poesía Popular. Colección de los viejos romances que se cantan por los asturianos en la danza prima, esfoyazas y filandones recogidos directamente de boca del pueblo, anotados y precedidos de un prólogo por... Madrid, 1885 (ed. facs. Madrid-Gijón, 1986) p. III-IV, VIII-IX.

17 BALbín De UnQuera, A.: «Miscelánea. Noche de invierno en la Aldea», en Asturias, Madrid, 172 (1899).
}

Hispania, LXII/3, núm. 212 (2002) 1059-1098 
la estación florida», o al rememorar placenteramente "el estado civil de sociedades aún sin firmes cimientos y sus costumbres sencillas y patriarcales». Otras veces las referencias al mundo rural aparecían descargadas de juicios de valor sobre el mundo del Antiguo Régimen; pero de todos modos eran ocasión para exhibir todo tipo de excesos líricos. La narración ganaba en asepsia argumental, pero los derroches literarios pintaban un universo alejado de las contradicciones sociales y demasiado apacible y bueno como para ser creído. Es así como la estructura de los más completos libros de folclore en Asturias, se caracteriza invariablemente por la presencia de unos prólogos adornados con todos los trinos de la lengua castellana. La descripción que se ofrece en el del libro comentado de Juan Menéndez Pidal, y en donde se alaban los sentimientos puros y candorosos del «ingenioso campesino", es un buen ejemplo de ello. Pero podrían ponerse muchas muestras similares y, entre otras, las de la espesa prosa de Constantino Cabal; un periodista, literato e historiador que empezará a desarrollar su labor esencial como folclorista a partir de los años veinte. La visión grata de lo campesino, sin embargo, lejos de limitarse al ámbito ideológico netamente conservador en el que se movía este último, también afectó a otros folcloristas. Aurelio de Llano, un antiguo y fugaz socialista que más tarde llegó a figurar entre los investigadores de folclore más rigurosos de la región, es buen ejemplo de ello. El prólogo a su clásica obra sobre El folklore asturiano, lo prueba con creces. Su estilo, por lo común austero, se desborda al describir «las veladas patriarcales escuchando - después de rezar el rosario- los romances, [o los] cuentos mitológicos, de princesas encantadas» o al contemplar «los pájaros cantar amores en las ramas floridas mientras fabricaban sus nidos» $y$ «elevarse en vuelo vertical y posarse en un rayín de sol, para romper en una fuente de trinos y verterlos en cascada sonora sobre el lecho de sus hijos, construido sobre una mata de tomillo». Naturalmente, es difícil encontrar en estos escritos testimonios o detalles de las transformaciones surgidas en la sociedad rural; porque de presentarse, se entendía que reflejaban una realidad impura y salpicada de imperfecciones que perturbaban la bondad de los tiempos pasados. Las novedades sociales e ideológicas introducidas por la industrialización, en consecuencia, eran entendidas como verdaderas profanaciones y, si se aludía a ellas, se hacía con una poca disimulada hostilidad. A J. Menéndez Pidal, por ejemplo, le ahogaba «La atmósfera de la industria, el humo de las fábricas y el ambiente tibio y perfumado de los salones», opuesto en todo al «ambiente de libertad y honrada sencillez en que vive el campesino».

La literatura de la época, como sabemos, opuso sistemáticamente la pureza del campo a una industrialización destructora de los apacibles ambientes rurales. El paradigma de este tipo de creación literaria de temática asturiana era, sin duda, la conocida novela de Armando Palacio Valdés, La aldea perdida, a la que se volverá más adelante; pero había muchos otros casos de similar apariencia. El «poema social» Ola negra, de Valentín de Lillo y Hevia era uno de ellos. Sus héroes son María y Pachín; hermosa y gentil la primera y, el segundo, hábil bailarín, triunfador en las competiciones populares y arrogante vencedor de las 
palizas — batallas a garrotazos que enfrentaban periódicamente a los mozos de las parroquias vecinas-. Pero la paz de su hogar de recién casados se romperá fatalmente cuando se le proponga cambiar su aldea por la mina:

\author{
«deja esa hacienda, al fin, que te arruina; \\ ven conmigo a la mina \\ que es el vivir aquí vivir muriendo; \\ estás el año entero trabajando: tu siembras \\ y cuando ves que el tiempo se avecina \\ de conducir los frutos al granero, \\ ¡Ay! Entonces, Pachín, ¿Cómo te hallas? \\ como trucha cogida entre las mallas \\ entre el fisco, el señor y el usurero».
}

Así pues Pachín emprende el camino hacia la villa minera, descrita con tonos inquietantes. Eran aquellos unos dominios por donde «las montañas/[...] por cien bocas, cual de horribles fieras,/ vomitan el carbón por sus entrañas»; donde el «río,/ de embetunadas aguas cenagosas,/ que fueron cristalinas y sabrosas» contrasta con la pureza de los arroyos de antaño; el lugar en donde «avanza la veloz locomotora,/ bramando enfurecida;/ cual monstruo horrendo»; el sitio, en fin, en «donde empiezan las grises lontananzas, / [y] una fábrica inmensa ver se deja». El protagonista, además, conocerá las temibles tabernas y, entre vaso y vaso, las teorías del «Judío Alemán». El héroe del poema, en fin, concluye su vida cuando es arrastrado a una manifestación, siendo abatido a tiros por la Guardia Civil mientras su mujer cierra llorando los últimos versos del poema ${ }^{18}$.

La literatura folclorista, entre tanto, idealizaba también otras virtudes del campesino y, entre ellas, la de la piedad religiosa; soslayando así los muchos indicios de paganismo, de prácticas heterodoxas o de conflictos con los párrocos de las comunidades rurales. En general, puede decirse que no fueron muy atendidas las advertencias que Félix de Aramburu había hecho sobre la tendencia a hablar más de lo debido de «lo patriarcal de las costumbres», o «del imperio ejercido en las conciencias por el principio religioso». Pudieron así formularse juicios tan audaces como los del folclorista e historiador Bernardo Acevedo y

18 MenÉndez PIDAL, J.: opus cit., p. III-IV, VI, XII-XIII, y 12 (sin subrayados en el original); LLANO, Aurelio de: Del folclore asturiano. Mitos, supersticiones, costumbres, Oviedo, 1922, p. XVIIIXIX; LILlo y HeVIA, Valentín de: Ola negra, Madrid, 1906, p. 7 y 20-21. Sobre la taberna en Asturias, puede consultarse URíA, J.: «La taberna en Asturias a principios del siglo XX. Notas para su estudio», en Historia Contemporánea, 5 (1991), y del mismo autor, «Ocio, espacios de sociabilidad y estrategias de control social: La taberna en Asturias en el primer tercio del siglo XX", en ReDERO, M. (ed.), Sindicalismo y movimientos sociales. Siglos XIX y XX, Madrid, 1994, pp. 73-97. Sobre el despliegue en la literatura española de los sentimientos antiindustrialistas y la vuelta a la naturaleza y al «pueblo», resulta de obligada lectura el libro de LITVAK, Lily: Transformación industrial y literatura en España (1895-1905), Madrid, 1980.

Hispania, LXII/3, núm. 212 (2002) 1059-1098 
Huelves, para quien «La Prehistoria y la Historia nos llevarían desde el bosque misterioso, antiguo templo del druida, hasta la basílica del Salvador para enseñarnos que la idea religiosa de un sólo Dios, el dios sin nombre; o el Dios del Calvario, inflamó siempre el corazón de los astures». Adoptar estos puntos de partida podía tener consecuencias de cierta envergadura. Juan Menéndez Pidal, precisamente, al clasificar los materiales de su compilación de romances, había optado por una triple categorización según fuesen religiosos, novelescos o históricos; dado que la religión, el amor y la patria eran «los caracteres que sellan y distinguen a esas poéticas creaciones». En definitiva, quizás la naturaleza de los materiales folclóricos llevase, en parte, a esas conclusiones; pero cabe poca duda de que tales criterios clasificadores orientaban también previamente su propio trabajo de campo. Lo que es más, incluso en el caso de folcloristas de conocida solvencia, los hábitos culturales o la simple moral dominante, conducía a retratos muy selectivos de los ingredientes culturales campesinos. De hecho, y «por razones que no necesitan explicación», decía Aurelio de Llano, no se llegó a dar a la imprenta gran parte de los cantares referidos a clérigos que había recogido en sus excursiones por Asturias. El folclore siempre había sido muy explícito en los vicios, de la gula o la lujuria por ejemplo, que se les atribuían a los sacerdotes ${ }^{19}$.

Con criterios selectivos de esta naturaleza, por tanto, no puede extrañar que el duro oficio del campesino pudiese compararse con los bucólicos ambientes de la literatura latina. Para aquellos folcloristas el campo descrito en sus prólogos era, antes que tierra de labor, paisaje; y pasar de una realidad con aspectos no siempre gratos a la pura poesía, constituía un tránsito aparentemente fácil y expedito. Véase si no el prólogo a la obra de C. Cabal Del folklore de Asturias:

La luz se hace caricia y suavidad; en el bosque de robles seculares o castaños imponentes, es como rayo de sol que se disuelve en la fronda... El bosque es misterioso y religioso; tiene columnas inmensas; tiene caminos ocultos abiertos a la poesía, pero que no se sabe a donde van. Las ramas se entrelazan y confunden; las raíces se asoman para verlas, manchadas por la tierra y por el musgo, retorcidas en forma de tentáculos... hay un vivo trinar de pajarillos... A veces, de árbol a árbol, hay una tela de araña de sutilísimo encaje que retiene, a manera de diamantes, unas gotas de rocío o unos rayuelos de sol. [...] Y hay un pasar perpetuo de bucólica, suavísima, virgiliana [manera], con un Títiro aldeano y una pareja de bueyes...»

El texto de Constantino Cabal, resulta muy significativo de muchas otras obras suyas, donde evoca reiteradamente la «Asturias eglógica». Pero el mundo rural cotidiano, naturalmente, distaba bastante de la paz y sosiego necesarios

19 ARAmburu, Félix de: Monografía de Asturias, Oviedo, 1899, p. 67; ACEvedo y HuElves, Bernardo: Los vaqueiros de alzada en Asturias, Oviedo, 1893, p. VIII; MENÉndeZ PIDAL, Juan: Poesía popular..., opus cit., p. 20; LLANO, Aurelio de: Esfoyaza de cantares asturianos, Oviedo, 1924, p. 138.

Hispania, LXII/3, núm. 212 (2002) 1059-1098 
para poder recostarse con tranquilidad y tocar el caramillo sub tegmine fagi. En realidad la jornada campesina, con ser algo más llevadera que la de los obreros industriales, dejaba poco espacio para tales expansiones, y desde luego, cabe dudar muy seriamente de que los folcloristas imaginasen los campos rurales asturianos poblados, como lo estaban los de las églogas, de pastorcillos como Coridón, enamorados inflamadamente de otros zagales de su mismo sexo, como el hermoso mancebo Alexis ${ }^{20}$. Pese a ello, la idea bucólica de unos campos supuestamente perfectos y amables siguió impregnando no sólo las elaboraciones folclóricas, sino otras producciones escritas entre las que cabe incluir, por supuesto, La aldea perdida de Palacio Valdés. Su alto valor para ejemplificar este ruralismo benévolo es indudable; el novelista no sólo es una buena muestra de la «escuela» narrativa asturiana de fines de siglo; a la vez, ilustra muy bien los gustos de un público de la Restauración que compraba masivamente sus novelas haciéndole uno de los pocos literatos que podía vivir desahogadamente de los productos de su creación literaria. El éxito de Palacio Valdés, por otra parte, hizo que se llevasen bastantes de sus novelas al cine, al teatro, o a guiones radiofónicos; su obra narrativa, en fin, había registrado un indudable éxito fuera de España y quizás fuese, junto con la de Blasco Ibáñez, una de las mejor acogidas entonces en el mundo anglosajón ${ }^{21}$.

La identificación entre la imagen de los campos y los equilibrios de la literatura y las épocas clásicas impregna por completo, desde el principio al final, las páginas de La aldea perdida. En particular, los esquemas de lo que Roland Barthes ha denominado "antigua retórica» dan a la obra una arquitectura lingüística omnipresente, que es necesario considerar como un recurso literario más a la hora de identificar el mundo rural con una realidad lejana, pero buena y perfecta; cualidades que aparecen fuertemente vinculadas a lo que entonces se entendía por clásico. Naturalmente estos esquemas son comunes a la oratoria y la prosa de la época; pero nunca con la intensidad de esta novela. Cualquier

20 CaBAL, C.: Del folklore de Asturias, cuentos, leyendas y tradiciones, Madrid, 1923 (ed. fasc. en Gijón, 1987), pp. 10-11; CABAL, C.: La mitología asturiana. Los dioses de la muerte. Los dioses de la vida. El sacerdocio del diablo, Madrid, 1925-1928 (ed. facs. en Oviedo, 1983) pp. 159. La afición a lo bucólico entre los folcloristas la certifican entre otras cosas la traducción por uno de los más insignes folcloristas españoles, D. Manuel MACHADO, de las Obras de Virgilio. Estudio crítico por Saint-Beuve. Versión castellana D..., París, s.f.. En su página 67 . Se incluye la versión de los célebres versos de las Geórgicas: «iTítiro! Tu, recostado bajo la sombra de esa frondosa haya, ensayas aires campestres con el blando caramillo; yo abandono los patrios confines y sus dulces campiñas huyendo del suelo natal, mientras que tu iOh Títiro! Acostado muellemente en la umbría, enseñas a las selvas a repetir el nombre de la hermosa Amarilis".

21 Una breve caracterización de esta «escuela» narrativa, en RUIZ DE LA PEÑA, A.: Introducción a la literatura asturiana, Oviedo, 1981, pp. 173-179. Una relación breve de los cargos y honores, así como de las traducciones de las obras de Palacio Valdés en SUÁREZ, C.: Escritores y Artistas Asturianos, Oviedo, 1957, tomo VI, pp. 15-41. Referencias a las derivaciones cinematográficas de las obras del novelista, en el artículo de Eugenio de Rioja: «Palacio Valdés y el Cine», en la Hoja del Lunes, Oviedo, 30-X-1953.

Hispania, LXII/3, núm. 212 (2002) 1059-1098 
lector que se haya familiarizado mínimamente con la lectura de las traducciones de clásicos, encontrará en la obra de $\mathrm{P}$. Valdés muchos de sus esquemas sintácticos y de su vocabulario, además de referencias constantes a las Geórgicas. Entre los lectores de clases medias era fácil identificar estas figuras y las referencias al mundo bucólico rememorando de inmediato, en consecuencia, un ambiente campestre quintaesenciado perfecta y placenteramente. Et in arcadia ego, decía el lema que abría el primer capítulo — titulado "Invocación»- de nuestra novela; y como en las antiguas liturgias paganas, donde la invocatio servía para solicitar la ayuda o intervención de alguna divinidad, en este prólogo se evocaba el armonioso mundo de la Arcadia; al igual que en las inmolaciones de víctimas en las épocas clásicas aquella novela, que acaba con el asesinato de dos de los protagonistas principales del paraíso rural, también empezaba con la invocatio preceptiva; y como en ciertas composiciones poéticas o musicales donde la evocación era un paso de rigor, nuestra historia se abría con un preludio parecido:

$\mathrm{Y}$ vosotras, sagradas musas, vosotras a quienes rendí toda la vida culto fervoroso y desinteresado, asistidme una vez más. Coronad mis sienes que ya blanquean con el laurel y el mirto de vuestros elegidos, y que este mi último canto sea el más suave de todos. Haced, musas celestes, que suene grato en el oído de los hombres y que, permitiéndoles olvidar un momento sus cuidados, les ayude a soportar la pesadumbre de la vida».

El capítulo inicial, además, parecía cumplir las normas de la argumentación retórica clásica. Como es sabido, la dispositio del asunto que se exponía a un público exigía, previamente al propio desarrollo de su argumentación (rem doce$r e$ ), un exordio inicial que sedujese al auditorio (captatio benevolentiae) y que además, en la partitio, anunciase las divisiones del asunto a tratar y el plan a seguir; de tal modo que, como decía Quintiliano, nunca pareciese largo algo cuyo término se anunciaba. En términos generales, las intenciones y las partes del exordio - dentro de la gran complejidad y flexibilidad de sus fórmulas estructuradas- se cumplen en esta «Invocación». Es presumible que lo amable del asunto descrito - la vida en la Arcadia - consiguiese seducir al lector; y en cuanto a la partitio, si bien en una obra literaria exponer la arquitectura del asunto pudiera menoscabar el suspense y la tensión de la historia, no hay duda de que su esencia se resume en los párrafos iniciales. Porque, en realidad, los protagonistas de la novela no eran los amores de Demetria y Nolo o de Jacinto y Flora; su verdadero eje lo constituía la historia de aquel paraíso rural, y de su trágica muerte a manos del progreso industrial. De este modo en el primer párrafo de la «Invocación» se describía aquel ambiente con la frescura y espontaneidad que había que suponerle a quien lo había conocido en su niñez — «iSí, yo también nací y viví en Arcadia!», dice la primera frase del capítulo-; y en el segundo párrafo, se anunciaba su trágica muerte: «La Arcadia ya no existe. Huyó la dicha y la inocencia de aquel valle [...]. Armados de piqueta cayeron 
sobre tí y desgarraron tu seno virginal y profanaron tu belleza inmaculada». En cualquier caso, el mundo de las églogas se asocia a lo rural en muchos otros lugares del texto, y no sólo en la introducción. Aunque tamizada por la ironía, la figura de Don César de las Matas de Arbín, es la encarnación de una maníaca adoración por la antigüedad clásica que, pese a sus exageraciones, plasma a la perfección los ideales que se sostienen en la novela, y en concreto, la defensa cerrada de la ruralidad feliz —o de la Arcadia, que tanto daba- frente a las novedades industriales. Así se explica que cuando Palacio Valdés describe la casa del señor de la Matas se sienta obligado a precisar irónicamente, como si de una anomalía se tratase, que la criada «no se llamaba Amarilis ni Mirtale, sino Pepa», o que Don César se entregue a menudo a reflexiones y ademanes donde lo eglógico ocupa un lugar no desdeñable; de este modo el personaje pasea enfrascado «en sus meditaciones clásicas y repitiendo en voz baja la hermosa égloga primera de Virgilio" hasta tenderse "sub tegmine fagi recitando cada vez con más fervor los versos del cisne de Mantua [...]. Se hallaba, pues, reposando dulcemente como Títiro» ${ }^{22}$.

Las exageraciones bucólicas no eran el único procedimiento enmascarador del mundo tradicional, ni afectaron sólamente a la creación literaria. En el folclore, incluso se había llegado a la pura adulteración. El prestigioso antropólogo Caro Baroja, acusó a la mitología asturiana de haber sido sometida a eruditas falsificaciones en la segunda mitad del siglo XIX; pero no es la primera vez que se lanza este reproche. Uno de los falsificadores más activos, según los hermanos Juan y Ramón Menéndez Pidal, parece haber sido Laverde Ruiz, maestro del famoso historiador reaccionario Menéndez Pelayo. De todos modos, y aún cuando los folcloristas no falsificasen los datos que recogían, no cabe duda de que se centraban más en las permanencias de la sociedad tradicional que en sus transformaciones; lo que resultaba llamativo en una sociedad cuyos cambios tuvieron que ser reconocidos, finalmente, por los propios folcloristas. Hacia 1920, según el propio testimonio de Torner, el decorado folclórico tradicional se había trastocado notoriamente: «Nuestros pastores — decía el folclorista - ya no lloran sus cuitas de amor al son del rabel o del caramillo, ni en las faenas del campo se emplean con tanta frecuencia las canciones dialogadas", y la causa de todo ello estaba en la «influencia de la moderna civilización, que en

22 Palacio VAldÉs, A.: La aldea..., opus cit., pp. 9-10, 83 y 135; BARTHES, Roland: Recherches Rhétoriques, Communications, $n^{0}$ 16, Paris, 1970, pasim. Para una visión de la teoría retórica de la época puede verse, desde el punto de vista eclesiástico, $\mathrm{MACH}$, José: "Oratoria Sagrada», tratado decimoquinto de su Tesoro del Sacerdote, Barcelona, 1882, p. 745 y ss.; véase también DíAz DE RUEDA, Ricardo: "Compendio de Retórica y poética», en La escuela de instrucción primaria o colección de todas las materias que comprende la primera enseñanza conforme al plan vigente, Valladolid, 1850. Este último librito, el Rueda, muy popular y conocido en las escuelas de Asturias, dedica a retórica y poética las pp. 151-189, poniendo a disposición de los escolares, de forma concisa, un amplio repertorio de mecanismos retóricos; los procedimientos del exordio citados en el texto, por tanto, no eran tan especializados como pudiera suponerse.

Hispania, LXII/3, núm. 212 (2002) 1059-1098 
nuestro país sólo tiene por ahora matices de industrialismo", y que se dejaba «sentir en los rincones más apartados de la provincia» ${ }^{23}$.

Veinte años antes, con todo, ese proceso distaba mucho de presentar un balance tan claro y el mundo tradicional, aunque en retroceso, todavía daba muestras de vigor. Nada tiene de particular, en esta perspectiva, que la idealización literaria del mundo rural se mantuviese con buena salud durante todo este tiempo. Armando Palacio Valdés, por tanto, no estaba sólo en absoluto; por el contrario, la literatura regional fue pródiga en ejemplos similares en la intención y en el esquema argumental, aunque con una calidad literaria más baja. Los modelos de estos idilios rurales estaban en la obra del propio P. Valdés y, por supuesto, en Pereda; el asturiano, en todo caso, era autor de obras de temática similar como El señorito Octavio (1881), El idilio de un enfermo (1883) Sinfonía pastoral (1931), o su mismo libro de memorias La novela de un novelista (1921). La aproximación de P. Valdés a visiones cada vez más gratas de la realidad campesina, y que mejor podían sintonizar con el universo de Pereda, fue un hecho; los registros naturalistas o las notas negativas de los personajes campesinos de sus novelas del siglo XIX, dieron paso a una visión mucho más plana y apacible de la sociedad rural en sus relatos del $\mathrm{XX}^{24}$. Pereda, en todo caso, fue el modelo explícito de obras como El río de mi valle. Novela de costumbres asturianas, del sacerdote Marcelino González; el autor confiesa en el prólogo, de hecho, su «deleite indescriptible» e «inexplicable fruición» ante las inimitables páginas de este "singular artista». Para el clérigo la montaña asturiana y la santanderina eran "hermanas gemelas", con escenas "afines, idénticos tipos, costumbres parecidas, el mismo sentimiento religioso, iguales paisajes...». Por qué, entonces, le decía una «voz interior», "no haces por el objeto de tus amores lo que por el suyo hizo Pereda?». El hecho de ser sacerdote aquel novelista no era algo fortuito; Pereda era uno de los pocos ídolos literarios de los sectores conservadores católicos, y referencia obligada en diarios clericales de la región como El Carbayón; los elogiosos editoriales del periódico a raíz de su muerte, en 1906, lo probaban sobradamente. La crítica literaria del diario, y en particular la interesante labor ejercida en este campo por su director, el canónigo Arboleya, insistió en la valoración positiva de autores como Pereda, dentro de un panorama literario donde no era fácil encontrar autores de clara ortodoxia religiosa. Los idilios rurales sobre la vida amable en el campo, en consecuencia, figuraron entre las obras favoritas del periódico, que incluso publicó en su «Bi-

23 MENÉndez PidAl, Juan: Romancero..., opus cit., p. 317; LlanO, Aurelio de: Del folclore..., opus cit., p. XI; Sobre el asunto de los personajes mitológicos aún terció C. CABAL, opinando en favor de la existencia de algunos acerca de los que A. de Llano se había pronunciado en un sentido negativo (Mitología asturiana... opus cit., p. 164-165). El texto citado es de Eduardo M. TORNER: Cancionero musical de la lírica popular asturiana, Madrid, 1920, p. XXXVIII-XXXIX.

24 GARCía DomíngueZ, E.: «La sociedad patriarcal en «La aldea perdida»«, en Boletín del Instituto de Estudios Asturianos, 63 (1968). GómEZ-FERrer, Guadalupe: Palacio Valdés y el mundo social de la Restauración, Oviedo, 1983, pp. 252-255. 
blioteca de «El Carbayón» « una buena muestra de ello en Desde la montaña (bocetos asturianos); obra de un tal Lucio Pérez, que no era otro que el canónigo Arboleya. El libro, pues, hay que considerarlo un manifiesto de los limitados ideales literarios del catolicismo social de la época, del que el autor era uno de sus más destacados exponentes en España ${ }^{25}$.

El periódico recibió «Là aldea perdida», a través de su crítico Maravillas - seguramente también Arboleya - con una emoción no contenida «con lágrimas en los ojos - decía-, llorando como un niño, devoré las páginas encantadoras de esa novela, que tal vez por referirse a mi pueblo, me pareció la más hermosa de las novelas». Con todo el mismo clérigo - esta vez con su propio nombre de pila - insistía en la necesidad de leer con tino al «Homero asturiano", aquejado a veces de las "brutalidades del naturalismo». Se le perdonaban, no obstante, estas «equivocaciones lamentables» considerando que había «enriquecido la literatura católica con sus tres últimas novelas, que con la anterior titulada «José», son de lo más sólido y perfecto de la novelística contemporánea. Los modelos de la «novela regional» que se defendían desde el periódico tenían que ver, como es lógico con estas coordenadas. Se trataba, otra vez, de vindicar al «hidalgo Pereda», rechazar «las procacidades del grosero naturalismo», y exaltar la «sencillez patriarcal de los rústicos habitantes de nuestras regiones». Lamentablemente los resultados literarios obtenidos en esta dirección fueron pocos y malos. La intención del autor de El Cantor de las Cumbres. Novela poemática, de costumbres asturianas, por ejemplo, era desarrollar a la altura de 1910 un «relato bucólico, en que revive su vida de égloga aquella tan dulce Asturias de antes que la profanaran los caminos de hierro y la desgarradora explotación de las minas...». El libro, sin embargo, llevaba un sonrojante prólogo del conocido dramaturgo y político Miguel Ramos Carrión que le calificaba de «equivocación lamentable» hecha con estilo «altisonante y enfático». El tema, en manos literariamente tan torpes no daba para mucho más, y en los años posteriores a la Guerra europea, estaba claramente agotado. En 1926, al reseñar con su habitual acidez Julio Somoza la novela de ambiente asturiano Isabelina (1924), de Constantino Suárez, apuntaba escuetamente: «Es sencillamente un ensayo de escritor novel, de escuela localista (avilesino), y de asunto trivial y manoseado.- La aldea perdida de Don Armando, va a perder a muchos ${ }^{26}$.

25 GONZÁlEZ, Marcelino: El río de mi valle. Novela de costumbres asturianas por..., Oviedo, 1908 , pp. VII-IX. El Carbayón, Oviedo, 5-III-1906, 26-III-1906, 26-II-1907. PÉREZ, L.: Desde la montaña. Costumbres asturianas. Oviedo, 1906. Sobre Arboleya, véase BENAVIDES, D.: El fracaso social del catolicismo español. Arboleya Martínez 1870-1951, Barcelona, 1973.

26 Maravillas, «La aldea perdida. I», El Carbayón, 16-II-1903; ARBOleYA, M.: «La obra de Palacio Valdés», ibid., 5-IV-1906; MÉNDEZ, L.: "Literaria. La novela regional», ibid., 12-VII-1913. NAVA VAldÉs, Antonio: El Cantor de las Cumbres. Novela poemática de costumbres asturianas, Madrid, 1910, pp. 13-16 y 27. SOMOZA GARCíA-SALA, Julio: Registro Asturiano de obras, libros, folletos, bojas mapas y ediciones varias, exclusivamente referentes al Principado, que no se hallan en Bibliografías anteriores por..., Oviedo, 1926, p. 391.

Hispania, LXII/3, núm. 212 (2002) 1059-1098 
La verdadera égloga, la literariamente viable, había sido en su tiempo la de Palacio Valdés, que había conseguido con éxito poner su capacidad fabuladora el servicio de una imagen del campo sospechosamente ajena a las tensiones o conflictos. Su visión de las romerías de su infancia encajaba, por ejemplo, en estos presupuestos. Como decía el novelista allí no «existía la lucha de clases, y la prueba es que muchos señoritos abandonaban el círculo de sus iguales y se introducían en el de las artesanas sin que los obreros se diesen por ofendidos». Pero seguramente mentía, o se refería tan solo al escenario del Avilés de su infancia. Precisamente en La aldea perdida, había dejado una descripción famosa - y nada pacífica - de las palizas interparroquiales, una forma de violencia institucionalizada que enfrentaba sistemáticamente a garrotazos a las comunidades parroquiales vecinas. Sus consecuencias de heridas, magullamientos y agresividad no formaban parte, sin embargo, de las descripciones del novelista. Tales asuntos habían dado que hacer, desde siempre, al sistema judicial de la región, y en particular desde finales de siglo XIX, cuando los garrotes empezaban a ser sustituídos por navajas o pistolas. Pero tal y como lo veía el autor, aquello podría haber pasado perfectamente por un pasaje de obras como $D e$ Bello Gallico.

«Cuando los de uno y otro bando se hubieron encontrado, sonó un formidable clamor [....]Como dos ríos impetuosos que caen de la montaña [...], así los dos ejércitos rivales cayeron uno sobre el otro. Igual furor les anima; el mismo deseo de gloria agita sus corazones.

Sin embargo, los de Entralgo eran menos numerosos, y ante la avalancha formidable de sus enemigos no tardaron en ceder terreno. Entonces Nolo de la Braña $[$...] lanzó un silbido penetrante.

Los cincuenta guerreros de Fresnedo, Meloneras y Navaliego, al oír aquella señal, surgieron de improviso del bosque donde se hallaban ocultos y cayeron como buitres hambrientos, lanzando gritos horrísonos, sobre los mozos del Condado y Lorío. ¿Quién pudiera resistir el ímpetu de aquella juventud magnánima?. Una tromba de agua y pedrisco no causaría más daño en un sembrado; la mar alborotada, arrojando sobre la tierra sus espumas amargas, no infundiría más espanto [...]. En vano el valeroso Firmo de Rivota [...]se arroja con temerario coraje en medio de la pelea. [...]

-Musas, decidme los nombres de los guerreros que allí cayeron o salieron descalabrados bajo los garrotazos de los hijos de Entralgo, porque yo no acierto a contarlos» ${ }^{27}$.

27 PalaCio Valdés, A.: La novela de un novelista, en Obras, Madrid, 1959, vol II, p. 705; La aldea...opus cit., pp. 165-166. A las transformaciones acaecidas en la paliza interparroquial se alude en URÍA, J.: «De la fiesta tradicional al tipismo mercantilizado. Asturias a principios del siglo XX", en Bulletin d'Histoire Contemporaine de l'Espagne, Burdeos, 30-31 (1999-2000).

Hispania, LXII/3, núm. 212 (2002) 1059-1098 


\section{LA RUPTURA DEL EQUILIBRIO TRADICIONAL.}

Quizás esta literatura rural abusase de elementos heroicos. Pero Palacio Valdés tenía éxito y, si era así, quizás había que interpretarlo como una prueba de que se estaba escenificando un ambiente en parte verosímil. Y en efecto, también aquí, como en otros casos de la cornisa cantábrica, podía establecerse un cuadro más halagüeño del campesinado en relación con las duras condiciones del jornalero del sur. La estabilidad social de la región solía asociarse a la existencia de pequeños propietarios, la subsistencia de unas relaciones de producción tradicionales, y un relativo aislamiento de los ambientes rurales. Los datos sobre la estructura de la propiedad en Asturias durante el siglo XIX siguen siendo, en todo caso, exasperantemente dispersos, lacónicos y difíciles de interpretar. En el transcurso del siglo XVIII, al parecer, se había producido un claro retroceso de la pequeña propiedad en todo el norte de España y, muy especialmente, en Asturias. Las nuevas roturaciones y la privatización de los bienes de uso comunal, que se habían intensificado ya desde finales del siglo XVIII continuaron en la primera mitad del siglo XIX aprovechando el vacío de poder y la desorganización administrativa que acompañó a la Invasión napoleónica; ello fortaleció una exigua propiedad campesina aunque, como es lógico, los principales beneficiarios del proceso fueron los grandes propietarios. Las oportunidades abiertas por la desamortización de Mendizábal permitieron, especialmente en el transcurso de los años cuarenta y cincuenta, aumentar algo más el número de pequeños propietarios. La existencia de esta pequeña propiedad en las décadas centrales del siglo XIX era, pues, una modesta realidad; especialmente en lugares próximos a núcleos urbanos consumidores como Gijón, favorecida por la especialización ganadera u hortofrutícola y la consiguiente mercantilización de sus productos. En la segunda mitad del siglo XIX la desamortización de Madoz, asimismo, permitió también el acceso de un limitado número de campesinos a la propiedad, aunque su progreso fue discreto frente a una gran propiedad plenamente consolidada. Hasta los años ochenta, desde luego, la impresión general es la de que la pequeña propiedad no representaba gran cosa respecto a la grande o al colonazgo. En el año 1864, por ejemplo, el número de colonos duplicaba al de pequeños propietarios, y datos posteriores, en los años ochenta, abundan en porcentajes similares e incluso en proporciones más desfavorables dependiendo de las comarcas; las informaciones manejadas por F. Erice o R. Domínguez, en fin, no sugieren en absoluto cambios espectaculares en este terreno, sino que indican que la pequeña propiedad está recluída en unos porcentajes minoritarios de superficie con respecto a la media o la grande. Su desarrollo posterior, en todo caso, sería muy lento; en los años veinte de la siguiente centuria, por ejemplo, algunas estimaciones indicaban que la gran propiedad abarcaba a una cuarta parte del terreno en explotación, un tercio abundante pertenecía a unos 4.000 "terratenientes menores", y el resto era adjudicable a propietarios pequeños de ínfimas parcelas o 
fincas sueltas, lo que vuelve a indicar una minoría de pequeños propietarios frente al resto de los tenentes de la tierrra ${ }^{28}$.

La presencia de la pequeña propiedad, en todo caso, empieza a ser una realidad cada vez más firme en el transcurso del siglo XX. La apropiación de comunales se dinamiza en ciertos municipios desde principios de siglo, aunque su legalización no se producirá en muchos casos sino hasta los años veinte de la misma centuria. Asimismo, en algunas áreas asturianas se puede documentar desde finales del siglo XIX y principios del XX un relativo desinterés de los grandes propietarios por sus bienes agrarios traducido en una detención en el proceso de compras de parcelas, e incluso la venta de los mismos para reinvertir sus capitales en actividades más lucrativas.La disminución de las grandes propiedades es ya apuntada por A. Buylla a principios de siglo XX pero el proceso, en todo caso, debió de ser muy desigual geográficamente y muy lento en su desarrollo cronológico; de hecho, todavía en 1955 se calculaba en un $44 \%$ la superficie cultivada mediante la fórmula del arriendo. Ahora bien, incluso considerando su escaso relieve comparativo no puede obviarse la importancia de la pequeña propiedad en la región. Por mínima que fuese, podía apuntalar una explotación que también se componía de arriendos o de una densa red de aprovechamientos comunales de los montes - exceptuados del proceso de ventas abierto con la desamortización- que soportaban una explotación ganadera cuya importancia iba claramente en aumento. La composición tradicional de la cabaña ganadera, en su mayoría ovino y caprino todavía a mediados del siglo XIX, se irá alterando en beneficio del vacuno debido a la creciente demanda en los núcleos urbanos de productos lácteos o cárnicos. En los municipios de la

28 El esquema de la identificación de la pequeña propiedad y la mayor estabilidad social, en García SAN Miguel, Luis: De la sociedad aristocrática a la sociedad industrial en la España del siglo XIX, Madrid, 1973, p. 181. Información sobre roturación de comunales, procedimientos de acceso del campesino a la pequeña propiedad, o estimaciones de su volúmen, en DOMínGUEz MARTín, R.: El campesino adaptativo. Campesinos y Mercado en el Norte de España, 1750-1880, Santander, 1996, esp. pp. 73-74, 169 y 171; RODRíGUEZ PARDO, Julio: Economía y sociedad. Un estudio sobre la montaña contro-occidental asturiana durante la crisi del Antiguo Régimen, Oviedo, 2000, pp. 17-23, 125-133, y

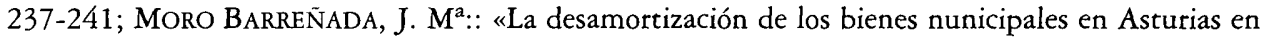
la segunda mitad del siglo XIX», en Boletín del Instituto de Estudios Asturianos, 88-89 (1976), p. 663; del mismo autor, La desamortización en Asturias en el siglo XIX (Gijón, 1981, pp. 207-212), «La desamortización de Madoz en Asturias» (en Estudios de Historia Social, 18-19 (1981) pp. 112-115) y «Propietarios y colonos en Asturias en el siglo XIX. Notas en torno a la propiedad y el uso de la tierra» (Ástura, 1 (1983); y ERICE, F.: «Comercio de granos y transformaciones agrarias en Asturias en la segunda mitad del siglo XIX", en Ástura, 4 (1985). Los datos de 1864 en Matías SANGRADOR Y VITORES: Historia de la administración de justicia y del antiguo gobierno del Principado de Asturias, Oviedo, 1866, p. 318-319. Un comentario de los datos dispersos sobre la propiedad desde mediados del siglo XIX hasta los años ochenta en ERICE, F.: Propietarios, comerciantes e industriales. Burguesía y desarrollo capitalista en la Asturias del siglo XIX (1830-1885). Oviedo, vol I, pp. 53-77. Los datos de los años veinte, comentados por Erice, son de Fermín GARCía Bernardo: Agricultura actual y mejoras que reclama, Gijón, 1922 
montaña central asturiana, debido a sus condiciones ecológicas o a las buenas comunicaciones, en la segunda mitad de siglo ya se estimaban mucho más los prados que las tierras de labor; y en los años ochenta, en algunas comarcas como la de Caso, la cabaña ganadera se cifraba en unas 20.000 cabezas para un total de 1500 vecinos.

En otro orden de cosas, y en cuanto a los arrendamientos, fuesen del tipo enfitéutico del foro, o limitados a un número corto de años, su carga económica para el campesino parece haber sido en general tolerable. Naturalmente, ello no eliminaba la estructura desigual de la sociedad campesina, ni la existencia de otras modalidades de apropiación de la renta de la tierra; los prestamos abusivamente usurarios entre el campesinado daban buena cuenta de ello. Pero distintos testimonios, y algunos de cierta calidad, coinciden en algunos puntos de particular interés a nuestros efectos. Al parecer, ni las rentas llegaban a niveles insoportables, ni solía darse una inestabilidad acusada en cuanto a la tenencia de la tierra. En 1883, por ejemplo, un antiguo alumno de la Universidad de Oviedo, el prestigioso historiador y jurista Gumersindo de Azcárate, sostenía en su Ensayo sobre la bistoria del derecho de propiedad que en «algunas comarcas de España, como Asturias, los arrendamientos son en gran parte; de hecho, hereditarios, sin que cambien ni el colono ni la renta». En abril de 1885, por otra parte, se fechaba el informe referente a la provincia de Oviedo correspondiente a la Información oral y escrita abierta por la Comisión de Reformas sociales, y luego publicada en 1893. En el documento se volvía a insistir en la existencia de "pocos grandes propietarios, regular número de medianos, y considerable de pequeños»; y además de ello, se subrayada el carácter común y ordinario en la provincia del contrato de foro, y el hecho de que cuando se sustituía por un contrato cuatrienal, por lo común la tierra se disfrutaba vitaliciamente y hasta de modo hereditario ${ }^{29}$.

29 El dato sobre la superficie afectada por los arrendamientos en los años cincuenta, en FIGAR ÁlvAREZ, G.: «Panorama actual de la agricultura asturiana», en Conferencias sobre economía asturiana, Oviedo, 1955, vol I, p. 81. Véase también, RODRíGUEZ GUTIÉRREZ, F.: La organización agraria de la montaña central asturiana, Oviedo, 1989, pp. 125, 345, 357; BUYLLA, A.: «El obrero agrícola Asturiano", en La proteción del obrero (acción social y acción política), Madrid, 1910, pp. 88-89. FERNÁNDEZ GARCÍA, Felipe: «Estructuras agrarias y usos del suelo en la parroquia de Deva (Gijón)», en Ería, 4 (1983); Pedregal, M.: «Apuntes sobre el derecho de propiedad», Boletín de la Institución Libre de Enseñanza, t. VIII (1884), pp. 225-230; QuiRós, F.: «Asturias en el Madoz», en, MADOZ, P.: Diccionario Geográfico-Estadístico-Histórico. Asturias, facsímil de la edición de 1845-1850 en Valladolid, 1985, pp. II-V; GoNZÁleZ PARDO, J.: opus cit., pp. 57 y 109-110. Sobre la extensión del crédito entre el campesinado asturiano, véase el trabajo de MORO, J. M $M^{\mathrm{a}}$ y ERICE, F.: «Crédito y campesinado en la Asturias del siglo XIX", en SAAVEDRA, P. y VilLARES, R., eds.: opus cit., pp. 216-245; el artículo adelanta conclusiones más firmes en la obra de los mismos autores Crédito y endeudamiento en la Asturias del siglo XIX, Oviedo, 1999. Sobre la preservación de los montes del proceso desamortizador, véase MORO, J. M ${ }^{\mathrm{a}}$ : "Los montes públicos en Asturias a mediados del siglo XIX», en Agricultura y Sociedad, 12 (1979). El texto de Azcárate se cita en la monografía de PRIETO BANCES, R. sobre «La casería asturiana», en Obra Escrita, Oviedo, 1976, tom. I, p. 424; sobre la presencia de

Hispania, LXII/3, núm. 212 (2002) 1059-1098 
Junto con las características de los arriendos, el disfrute de los comunales era otro de los datos decisivos para establecer las magnitudes y la viabilidad de las explotaciones campesinas. Como ya se ha señalado, la posesión de ganados era muchas veces un indicio más seguro que la tenencia directa de la tierra a la hora de determinar el nivel de vida o la simple entidad de la explotación campesina. El ganado - y sobre todo vacuno, para destinarlo a la comercialización-ocupaba ya un papel importante en la explotación campesina en las décadas finales del siglo XIX, y constituía una tendencia sólidamente afirmada desde principios del XX. La expansión ganadera, en todo caso, no tenía por qué traducirse necesariamente en la posesión por parte del campesino del ganado, ni mucho menos en la percepción de lo principal de sus beneficios, debido a la extensión de la aparcería ganadera (la comuña). Pero desde principios de siglo XX la proliferación de los sindicatos agrarios y, muy especialmente, de las cajas de seguros sobre el ganado que solían integrarse en ellos, sentó unas nuevas bases en la contratación limitando los riesgos de la inversión, y facilitando plataformas de acumulación más firmes para el campesino. La ganadería, pues, se estaba convirtiendo en un sector dinámico, mercantilizado, y cada vez con más atractivo para el campesinado y su importancia se hacía cada vez más perceptible. El viraje ganadero de las explotaciones era evidente; en 1915 la superficie dedicada a usos ganaderos quizás suponía un $58 \%$ del suelo, sumando los prados y los comunales; en esa misma fecha el ganado vacuno totalizaba ya las 285.348 cabezas, frente a cantidades sensiblemente menores de lanar (128.438) y de cerda (116.823). En 1931, en fin, las producciones ganaderas suponían un valor de 221.300 .000 pesetas frente a unas producciones agrarias que se quedaban en las 180.194.000; los avances de la mercantilización en ese momento suponían que la producción cárnica asturiana aportaba el $10 \%$ del total español, siendo los lácteos el $18,70 \%$ de la producción nacional ${ }^{30}$.

\footnotetext{
Azcárate en Oviedo, véase el artículo de El Carbayón, Oviedo, 28-VIII-1903; véase también Reformas Sociales. Tomo $V$. Información Oral y Escrita practicada en virtud de la Real Orden de 5 de diciembre de 1883, Madrid, 1893, (ed. fcs. Madrid, 1995, p. 377-378. Las conclusiones sobre la situación en el campo son similares al informe de Buylla sobre «El obrero agrícola asturiano», referido a principios de siglo, e incluido en el volumen ya citado.

30 Sobre la evolución ganadera en el siglo XIX vid. ERICE, F.: opus cit., tom. I, p. 54-57, y GARCÍA PARDO, J.: opus cit., pp. 62-63 y 140. La alusión a la roturación de comunales y sus modalidades, en Reformas sociales...opus cit., p. 379; faltan aún, de todos modos, monografías locales que sigan este proceso en los distintos municipios asturianos. La generalización de la aparcería en los años ochenta del siglo XIX, es reconocida en la misma encuesta de la Comisión de Reformas Sociales (p. 378). Sobre los sindicatos agrarios véase FERnÁnDEZ, B. y GiRÓN, J.: "Aproximación al sindicalismo agrario en Asturias (1906-1923)», en M. TUÑón DE LARA (et alii) La cuestión agraria en la España contemporánea, Madrid, 1976; y URÍA, J.: Sociedad, ocio y cultura en Asturias (1898-1914), Oviedo, 1991 (microforma), pp. 659-768. Los datos de 1915 en NAREDO, M. y BAJO, F.: El ganado bovino de Asturias, Madrid, 1916; los de 1931 en ARGÜELLES, R.: Regionalismo económico asturiano, Gijón, 1934, pp. 25-27.
} 
Esta compleja unidad de explotación campesina, solía presentarse asociada a un universo tradicional cuya persistencia se constataba tanto en la organización productiva como fuera de ella. El aislamiento y la dispersión de los núcleos rurales constituía un factor que, indudablemente, había hecho más difícil la penetración de las novedades urbanas, acentuando la marginalidad de las áreas campesinas. En 1900 el $96 \%$ de los núcleos de población asturianos tenían menos de 100 habitantes, y la proporción apenas varió en años sucesivos. El trazado del ferrocarril, sólo tenía 263 kilómetros para los 11.000 kilómetros cuadrados de una región de orografía atormentada. Las vías férreas, en todo caso, únicamente comunicaban el centro urbano de la región con Castilla, ignorando su occidente y siendo incapaz de conectar, por el oriente, con la vecina provincia de Santander; quedándose las líneas a unos 23 kilómetros del límite provincial. Los viajes en diligencia, entre tanto, eran caros y lentos; los 102 kilómetros del recorrido entre Pola de Allande y Oviedo, tardaban en hacerse unas 16 o 17 horas en 1904; el precio de un billete a Madrid a mediados del siglo XIX costaba, en berlina, el equivalente al sueldo de un capitán del ejército; y en baca, al de un artesano. Hacer el recorrido era, además, una aventura, y el mal tiempo, los aludes, y accidentes de todo tipo disuadían a muchos de emprenderlo. En 1902 El Carbayón denunciaba el estado de unas carreteras «tan abandonadas que da lástima verlas», debido al «lodo, que hace imposible el libre tránsito»; y en algunos lugares, como en Grado en 1907, las parroquias cortaban su contacto durante el invierno con las pequeñas villas cabeceras de las comarcas - a unas 4 o 5 horas de distancia- debido a las nieves o las torrenteras del deshielo. En 1904, en fin, todavía había que entrar a caballo, o a pie, en unos 30 distritos municipales (concejos) de los 78 de que constaba la región. En sus montañas había caminos donde el lodo no sólo era una realidad natural debido a la pluviosidad, sino que los propios campesinos la fomentaban echando en su piso substancias vegetales para obtener, mediante la fermentación consiguiente, cantidades adicionales de abono. La relativa variedad y especialización tipológica de los trineos en estas áreas, se adaptaba a este tipo de vías de comunicación ${ }^{31}$.

El automóvil tardó, en consecuencia, en adaptarse a este medio. Uno de los primeros ómnibus de viajeros - a vapor, y con 9 toneladas de peso- se hundió a principios de siglo en un puente de balsas destinándosele después al desguace. Además, y como llegó a suceder en otras partes de Europa, los automóviles fueron boicoteados por los campesinos, temerosos del daño que podían infligirles a ellos o a sus ganados, emprendiéndose boicots cada vez más decididos e incluso llegando a lo que la prensa denominó «Guerra contra los “au-

31 Horarios y distancias de ferrocarril en Gutiérrez MAYo, J. y Álvarez URÍA, G.: Guía general de Asturias para 1904, Gijón, 1904; los costos de los billetes en CASARIEGO, J. Evaristo: Caminos $y$ viajeros de Asturias, Oviedo, 1979, pp. 80-81. Véase también El Carbayón, 15-11-1902; FerNÁNDEZ DE MIRANDA, A.: Historia de una comarca asturiana. Grado y su concejo, Madrid, 1907, p. 44. Más detalles sobre las comunicaciones en URíA, J.: Sociedad... opus cit., pp. 34-73

Hispania, LXII/3, núm. 212 (2002) 1059-1098 
tos"». En realidad la comunicación era problemática en varios aspectos. La información proveniente de zonas urbanas era difícil o implicaba retrasos de uno u otro modo. El teléfono tenía una red que databa de 1888, y que en 1899 cubría esencialmente las ciudades de Gijón, Oviedo y Avilés. El telégrafo, a su vez, disponía de 37 estaciones en 1904, bastantes de las cuales eran para uso exclusivo de los ferrocarriles, sin cubirse los concejos montañosos e interiores y los extremos oriental y occidental de la región. El servicio habitual de correos, continuaba siendo el medio más barato y eficaz y el que seguía garantizando la comunicación existente entre los aldeanos y los miembros de su familia emigrados a América. Pero dependía fatalmente del estado general de las comunicaciones por carretera, y su organización era a finales del siglo XIX caótica y afectada por numerosos extravíos o retrasos. En 1911, algunos periódicos habían calculado velocidades de transmisión de cartas que en ciertos trayectos llegaba a los 229 metros por día ${ }^{32}$.

Ese ambiente de relativo aislamiento contribuía a la pervivencia de un universo tradicional en el que la literatura y la mitología popular, o las creencias de tipo mágico o religioso elemental, fortalecían un conjunto ideológico que finalmente, y pese a las tensiones y conflictos que traslucía, no dejaba de contribuir al fortalecimiento del orden social establecido. En aquella rica y variada tradición oral eran apreciables ingredientes potencialmente subversivos con respecto a los valores dominantes en la sociedad rural; los elementos anticlericales -extendidísimos, pero no hechos públicos por los folcloristas- la rebelión contra instituciones como la de la familia, los crímenes pasionales o familiares, o el erotismo descarnado iban en esa dirección. Pero en general sus valores más firmes eran la religiosidad, la fidelidad al matrimonio, o la inteligencia y talento naturales como mecanismos de promoción social; además del mundo legendario de los castillos y las épocas pasadas. En definitiva, la estabilidad y el mundo apacible de lo establecido parecía volver a dominar en el complejo conjunto ideológico de las tradiciones orales campesinas ${ }^{33}$.

La aldea, perdida en su aislamiento, daba muestras de estar todavía a fines del siglo XIX, en ciertos aspectos, escasamente integrada en el mercado. Con-

32 Referencias a la producción de abonos en los caminos, pueden verse en MUÑíz PraDA, N.: Apuntes para la topografía médica del concejo de Mieres y su comarca minera, Oviedo, 1885, p. 40. Una alusión a la "guerra contra los autos» en el artículo del mismo nombre en El Noroeste, Gijón, 25-IX1907. Referencias a la red de teléfonos y telégrafos en CANALS, Salvador: Asturias. Información sobre su presente estado moral y material, Madrid, 1900, p.p 111-112. Velocidades de transmisión del correo, en La Unión Republicana, Oviedo, 24-I-1897; y El Carbayón, Oviedo, 12-VII-1905 y 13-I-1911.

33 Un análisis ideológico de las leyendas, mitos y literatura popular en URÍA, J.: Sociedad, ocio..., opus cit., pp. 147-259. Compilaciones folclóricas fundamentales para establecer el repertorio de la literatura popular, en MeNÉnDEZ PIDAL, J.: opus cit.; TORNER, Eduardo M.: opus cit.; LlANO, Aurelio de: Del folclore asturiano. Mitos, supersticiones, costumbres (Oviedo, 1922), Esfoyaza de Cantares asturianos (Oviedo, 1924); Cuentos asturianos recogidos de la tradición oral (Madrid, 1925); CABAL, C.: Del folclore..., opus cit.; La mitología asturiana. Los dioses de la muerte. Los diosos de la vida. El sacerdocio del diablo (Madrid, 1925-1928) 
viene, ciertamente, no perder de vista en ningún momento que desde principios de siglo la introducción de cultivos como la remolacha azucarera, los abonos químicos, o la creciente comercialización de productos como la leche o la sidra, estaban involucrando las haciendas de las caserías en unos mercados cada vez más amplios. La amortiguación de las crisis de subsistencias mostraba, por otra parte, una creciente accesibilidad a los cereales importados de menor precio y más regular aprovisionamiento; hacía tiempo además, según ya sabemos, que la comercialización de los excedentes ganaderos hacia el mercado cárnico era un hecho. Pero también lo era el que subsistían determinados hábitos productivos tendentes al autoconsumo. La dieta campesina, por ejemplo, a tenor de los datos exhibidos en distintos informes médicos u obras de historia local en el tránsito del siglo XIX al XX, muestra una tendencia a configurarse exclusivamente con productos autóctonos y procedentes de la propia explotación agrícola. A diferencia del obrero industrial, que desde los años ochenta al menos ya adquiría en los comercios carnes o grasas animales para condimento, o legumbres o productos no autóctonos como el arroz, la dieta de un campesino de Piloña en 1895 se componía, por orden decreciente en importancia, de pan de maíz, leche desnatada, patatas y castañas, alubias, y los indispensables 30 gramos de aceite para el condimento de tales productos. Era llamativo, asimismo, el hecho de que se siguiese cultivando escanda - un tradicional cereal de invierno de bajos rendimientos- cuando ya llegaban granos de Rusia o trigos castellanos a mucho más bajo precio. En 1908, de este modo, todavía se recogían en la comarca de Quirós unas tres mil fanegas de escanda y, lo que era aun más absurdo, se recolectaban mil en Gozón, al lado del puerto de Avilés por donde entraban los trigos extranjeros. Indicio del limitado radio de los intercambios era, asimismo, la vigencia de las viejas medidas de capacidad y de peso y la resistencia, a veces tenaz, a la adopción del sistema métrico decimal. Incluso en la propia capital regional, Oviedo, el alcalde se vio obligado en 1907 a transigir con las lecheras que bajaban de los pueblos con su mercancía y que, tras protagonizar diversos desórdenes, consiguieron revocar la orden que pretendía imponer las nuevas medidas en las ventas ${ }^{34}$.

34 ERICE, F.: "Comercio ...», opus cit., en Astura, 4 (1985). Informaciones sobre la dieta popular en CANella, F.: «Piloña, Infiesto», en Bellmunt, O. y CANElla, F.: Asturias. Su bistoria y monumentos, bellezas y recuerdos, costumbres y tradiciones, el bable, asturianos ilustres, agricultura e industria, estadistica. Gijón, 1894-1900, vol. I, p. 373; y en MUNíz PRADA, Nicanor: Apuntes para la topografía médica del concejo de Mieres y su comarca minera Oviedo, 1885, pp. 40-43. Los datos de la escanda en ALVARGONZÁLEZ, C.: La escanda, su origen, su cultivo, Gijón, 1908, pp. 54-61. Los incidentes con las lecheras en El Noroeste, Gijón, 1-XI-1907. Los datos sobre la dieta campesina, en todo caso, han de manejarse con cierto cuidado; R. DOMíNGUEZ MARTÍN (El campesino..., opus cit., pp. 662-664) maneja datos sobre la dieta campesina de características similares a las esbozadas en Asturias, y referentes a contextos de todo el Norte de la España atlántica muy diferenciados entre sí, y que por tanto no siempre sugieren niveles de autoconsumo elevados; las producciones locales, de hecho, podían cubrir tan sólo una parte del consumo doméstico.

Hispania, LXII/3, núm. 212 (2002) 1059-1098 
En todo caso las aldeas, y en este punto también se adaptaban en principio a los estándares de la supuestamente armónica "comunidad campesina», seguían caracterizándose por una intensa sociabilidad. La vigencia de una compleja red de derechos y servicios comunitarios era una realidad vigorosa a principios de siglo. Pervivía la costumbre de la andecha, un sistema informal de ayuda comunitaria o familiar en las tareas de la casería; la cooperación vecinal en la conservación de los caminos mediante la sestaferia; y, por supuesto, la costumbre del trabajo colectivo agrícola en los campos de labor comunales (erías). Esta última práctica se documentaba a principios de siglo en concejos como el de Amieva, San Martín de Oscos o Cangas de Narcea; la andecha y la sestaferia, aunque en decadencia, tenían una vigencia mayor y, en fin, la gestión colectiva de estas y otras tareas aún recaía en la reunión de la asamblea de vecinos (conce$y u$ ). De hecho, incluso en concejos como Piloña, en el centro de la región y en un área relativamente bien comunicada, ni siquiera la poderosa implantación del sindicalismo agrario había sido capaz de suplantar estas viejas formas comunitarias. Uno de los mecanismos simbólicos para fortalecer y cohesionar la comunidad local era, precisamente, la práctica reiterada de las palizas interparroquiales, que enfrentaban sistemáticamente en las épocas del cortejo y de las fiestas patronales veraniegas a los mozos de parroquias vecinas; sirviendo el encuentro y su preparación, o sus secuelas, para escenificar la coherencia y la personalidad específica de la unidad aldeana. La pelea interparroquial estaba, de hecho, presente constantemente en las recensiones de prensa que informaban de las fiestas veraniegas; y al parecer, si estas se celebraban en lugares remotos y de una ruralidad más nítida, la tendencia era a que la violencia o las manifestaciones de criminalidad fuesen más livianas que lo que sucedía en las áreas industrializadas ${ }^{35}$.

Todos estos datos, por tanto, parecían encajar en el modelo en general quieto y pacífico de la comunidad campesina, así como en la idea de unas colectividades apartadas de la civilización industrial, con abundantes rasgos arcaizantes, y remisas a abandonar un universo tradicional de supuesta armonía comunitaria. No debe olvidarse, sin embargo, que La aldea perdida, es una elegía que relata la vigencia pasada de un mundo que ya no existe en el momento de redactarse la novela, tal y como se reconoce en la «Invocación» inicial del relato. De hecho, muchos otros detalles desmentían los estereotipos de la «comunidad aldeana» mostrando una tendencia cada vez más clara a erosionar lo

35 La vigencia de estas costumbres comunitarias puede verse en obras como la de BELLMUNT, O. y CAmella, F.: Asturias..., opus cit. Sobre la andecha, véase García Fernández, J.: Sociedad y organización tradicional del espacio en Asturias, Oviedo, 1976, pp. 175-178. Sobre la sextaferia, puede comprobarse su vigencia en las Ordenanzas Municipales del concejo de Somiedo (Oviedo, 1897), las de Oviedo (Oviedo, 1908), o noticias variadas procedentes de la prensa. La información sobre Piloña, en El perfil de Piloña, Madrid, 1916, pp. 235-236. La lógica antropológica de la paliza se expone con toda claridad en Lisón TOlosana, C.: Antropología social en España, Madrid, 1971, p. 28. Informaciones de prensa sobre romerías con palizas, en URÍA, J.: Sociedad..., opus cit., pp. 279-280. 
tradicional y a integrarse en una moderna economía capitalista de mercado. En realidad cabría preguntarse, como lo han hecho ya varios especialistas en historia agraria, si la "comunidad campesina» tal y como la vio la historiografía o la ciencia jurídica de la época - Kropotkin, Joaquín Costa o Rafael Altamira, por ejemplo- había existido alguna vez.

Los trabajos de Domínguez Martín o de J. M. Cardesín demuestran, en este sentido, hasta qué punto el concepto de "comunidad campesina», entendida como una unidad social de base local con tendencias autárquicas, igualitariamente nivelada en su pobreza, heredera de un supuesto "comunismo primitivo», y destinada fatalmente a su disolución o degradación histórica por los embates del Estado o de un capitalismo expansivo y «superador» de sus caducas estructuras, respondía a una construcción escasamente respaldada por la realidad. Por el contrario, en lugares como Cantabria, puede observarse una realidad intrínsecamente desigual y jerárquica de tal modo que la comunidad campesina actuaba más como corporación que como comuna igualitaria, monopolizándose por sus patronos las decisiones verdaderamente determinantes de la misma. De igual modo la organización colectiva agraria, lejos de responder a estándares igualitarios o de marginalidad, mostraba cómo el mismo Estado procuraba promover los trabajos de interés común (infraestructuras de saneamiento o comunicaciones, por ejemplo) integrando la dinámica comunitaria, por tanto, en procesos más globalizadores; y cómo lejos de presentar comportamientos hostiles a la acumulación individual, la colectividad los permitía a través del reparto o la adjudicación a particulares de los comunales. El control de estos bienes y de las instituciones locales que los administraban se convertía así en vital, y el papel de los notables locales o «caciques» en decisivo ya desde el siglo XVIII. El carácter cerrado de estas economías tampoco parece, en fin, demostrarse en la práctica; ya desde el siglo XVIII la baja productividad y la escasez de tierras cultivables había empujado al campesinado a desarrollar estrategias alternativas para completar una explotación agraria insuficiente; y la ganadería, orientada tempranamente hacia el mercado, intentó cubrir gradualmente estas deficiencias. En Galicia, entetanto, tampoco parecen fiables los patrones de una comunidad campesina tradicional, atrasada y persistente a lo largo del tiempo. Tal y como subraya Cardesín, el modelo aplicado a Galicia, al igual que a zonas limítrofes del norte peninsular, presupone erróneamente una sociedad campesina afectada de un retraso estructural en el terreno tecnológico y productivo, y en el que se materializaría una estructura social dicotómica que enfrentaría a los señores rentistas con un campesinado depauperado, concebido como una colectividad homogénea en su subordinación a los propietarios a través de figuras contractuales igualmente «atrasadas». El autor rebate punto por punto estas cuestiones y, en particular, muestra una colectividad campesina más compleja y jerarquizada; en ella es posible distinguir categorías sociales, muy bien perfiladas en la memoria colectiva de la comunidad agraria, como la de los ricos, propietarios de tierras y arrendadores de ellas; los caseiros, arrendatarios de las mismas; los labradores, que basan su variable estatus en su doble calidad de 
propietarios o de arrendatarios; y las camareiras, mujeres solas o con hijos que trabajan a jornal y posesoras de unas pocas cabezas de ganado. A su vez, la inserción de la economía agraria gallega en el mercado nacional e incluso los inevitables contactos con el contexto económico mundial son asimismo tempranos. La explotación ganadera vuelve a ser el elemento fundamental de los cambios agrarios, y el vacuno orientará sus exportaciones en los años 60 hacia Portugal, en los 70 y 80 hacia Inglaterra, y desde esta última fase, una vez que se enlaza ferroviariamente Galicia con el centro peninsular, hacia Barcelona o Madrid. Los nexos del mundo agrario con el exterior de Galicia se densifican también en otras direcciones; esos años coinciden con la bajada de los precios de los cereales por la concurrencia de los trigos extranjeros, así como con la exportación de masas crecientes de mano de obra hacia América ${ }^{36}$.

Pero, aparte del escaso rigor de concepciones como la de la «comunidad campesina» en su empeño por codificar una imagen atrasada y estática de lo rural, es obvio que a finales del siglo XIX, y de forma cada vez más acelerada en el transcurso del siglo XX, los rasgos más obsoletos de este universo agrario están siendo rápidamente desplazados por una firme inmersión en el mercado, la capitalización de las explotaciones agrarias y, si las condiciones son favorables para el campesino, por unas actitudes cada vez más decididas a la disolu-

36 Las tesis de la inadecuación del concepto de comunidad campesina a la realidad gallega y santanderina pueden verse en los excelentes trabajos de DOMíngUEz MARTíN, R.: «La evolución de la comunidad campesina en Cantabria (1750-1950)» (en I Encuentro de Historia de Cantabria, Santander, 1996, tomo II, pp. 891-918) y «De l'aldea perduda a l'aldea recuperada: el mite de la decadència de la comunitat pagesa a Cantabria (1750-1950)» (en Recerques, 36 (1998), pp. 53-80); así como en el de CARDESín, J. M.: "El mito de la comunidad campesina: ¿crisis de un agente social, o crisis de un concepto dentro de las ciencias sociales?», en Concepcións espaciais e estratexias territoriais na bistoria de Galicia, Santiago de Compostela, 1993. Una visión de la tradicional oposición señores/rentistas en SAAVEDRA, P. y Villares, R.: "Introducción» a Señores y campesinos en la Península Ibérica, siglos XVIII-XX (Barcelona, 1991, pp. VII-XVII), que recoge las aportaciones del Simposio Internacional de Historia Rural en el que, de todos modos ya se observan síntomas de disidencia en cuanto a este modelo dicotómico clásico. Detalles sobre la diversificación social y la penetración del mercado en la economía agraria gallega, en CARDESín, J. M.: "Paysannerie, marché et État. La structure sociales de la Gallice rurale au 19é siècle», en Annales. Histoire, Sciences Sociales, 6 (1996), pp. 1331; y Tierra..., opus cit., pp. 169; para el caso de Cantabria, véase DomíngUEz MARTín, R. El campesino..., oopus cit.. Véase también el trabajo de A. MARTínEZ LÓPEZ: «Antecedentes del sector lácteo gallego, 1890-1935», en Agricultura y Sociedad, 59 (1991).Tanto en los trabajos de Dominguez Martín como en los de Cardesín se proponen alternativas nuevas a la inadecuación de conceptos como los de "comunidad campesina» o de «caciquismo»como categorías explicativas de la realidad social de la comunidad local agraria; en el primer caso substituyéndose por el de «comunidad cerrada o corporativa» de Samuel Popkin, y en el segundo proponiéndose conceptos como el de "red de relaciones» (en «Repensando el caciquismo: Espacio político y agencia social en la Galicia de la Restauración", en Historia y Crítica, II (1992) pp. 191-226). Sobre las derivaciones y principales planteamientos en la Historia del Derecho y la Antropología de la polémica sobre la «comunidad campesina» desarrollada en la $2^{a}$ mitad del siglo XIX véase Carlos GIMÉNEZ ROMERO: «La polémica europea sobre la comundiad aldeana (1850-1900)» en Agricultura y Sociedad, 55 (1990).

Hispania, LXII/3, núm. 212 (2002) 1059-1098 
ción de la organización comunal de la tierra. Tanto en Cantabria como en Galicia, son observables estos comportamientos. En la parroquia gallega de San Martiño de Castro, por ejemplo, y desde la primera década del siglo XX, se irán introduciendo todo un conjunto de nuevos aperos y maquinaria agrícola - hacia 1915 llega al lugar la primera trilladora a vapor-. En Cantabria, a su vez, la fase abierta a partir de 1900 inicia un período de competencia, cambio estructural y redefinición de lo comunitario; la apropiación de comunales para su conversión en pastos se intensifica, y avanza la mejora de las razas ganaderas o la industrialización de los productos lácteos. En Galicia y en Cantabria perdía cada vez más sentido la organización comunal de los cultivos, que entraba en contradicción con los nuevos métodos intensivos ganaderos y de producción de forrajes $^{37}$.

Tan interesante como todo esto, sin embargo, es observar que los comportamientos y la cohesión comunitaria de los campesinos siguen siendo una realidad coexistente con la penetración de sus economías por el mercado, o con la lenta disgregación de la organización comunal agraria; no se cumple, por tanto, el modelo de una modernización que implicaría la sustitución tajante del comunitarismo por el universo de la competencia individual y la insolidaridad entre los empresarios campesinos individuales. Por el contrario, el declive de lo «tradicional» era mucho más complejo; los campesinos, lejos de resignarse a una suerte que se les depara desde el exterior de su clase social, imponiéndoseles cambios por la fuerza inexorable de la industrialización, muestran ser capaces de resistir y de adaptarse a las nuevas condiciones adoptando un papel mucho más activo en la dinámica social. En Galicia, por ejemplo, los poderes locales comunitarios serán capaces de explotar los resquicios legales para prolongar la vida de los viejos sistemas agrarios colectivos o, a la inversa, para liquidarlos en virtud de un proceso privatizador dependiendo de sus intereses concretos. Al mismo tiempo, la existencia de tupidas redes de relaciones de corte clientelar y base local siguió otorgando un notable poder de cohesión a estas comunidades rurales a la hora de torpedear determinadas medidas administrativas que les perjudicaban o de imponer cambios que les beneficiaban. El exitoso boicoteo de los ayuntamientos a cualquier intento administrativo de aprensión o control sobre los montes municipales, o los repartos de comunales entre vecinos, ofrecen sendas muestras de ello. En Cantabria, a su vez, también se da un proceso de apropiación de comunales y de crecimiento de los pequeños y medianos propietarios a lo largo de la segunda mitad del siglo XIX, prolongándose estas tendencias iniciado el siglo XX. El proceso, coincidente como ya sabemos con una mercantilización creciente, fue apoyado constantemente por decisiones de los propios campesinos amparados en la administración mu-

37 Cardesín, J. M.: Tierra..., opus cit., pp. 169-175 y 190; Domínguez Martín, R.: «Là evolución...», opus cit., pp. 909-912.

Hispania, LXII/3, núm. 212 (2002) 1059-1098 
nicipal y en el sindicalismo agrario; sin responder tan sólo, en consecuencia, a la presión de los grandes propietarios o de las empresas lácteas ${ }^{38}$.

Lo esencial de este complejo conjunto de procesos parece detectarse en Asturias, aún cuando se carezca de un caudal de monografías comparable al de Galicia o Cantabria. Para empezar, y pese a la probada pervivencia del trabajo comunal en muchos concejos asturianos y de costumbres como la de las asambleas de vecinos a toque de campana, tampoco aquí el sostenimiento de tales prácticas implicaba la ausencia de jerarquización o de desigualdades sociales. El médico e historiador José P. Ferrería, en una excelente obra de 1914, recordaría precisamente cómo ya desde el siglo XVII las herencias, las compraventas o los mayorazgos habían ido destruyendo la igualdad de derecho en el reparto de las suertes en que se dividía el terreno común de siembra; en las asambleas de vecinos, en consonancia, la desigualdad en el voto era un hecho; las casas nobles de la comarca, además, habían ido adquiriendo por compra los votos y, por tanto, controlando efectivamente estos organismos. En muchos casos, por consiguiente, las asambleas sólo deliberaban acerca de asuntos de mero trámite o de interés secundario. Naturalmente, la desigualdad social sequía siendo una realidad bien contrastada a lo largo del siglo XIX. Al menos hasta los años 80 del siglo XIX, como ya sabemos, la dureza de las condiciones en los arriendos siguió siendo un hecho; y la necesidad de acudir al préstamo implicaba una sangría adicional de los menguados recursos campesinos ${ }^{39}$.

Pero si los viejos esquemas de la «comunidad campesina» nunca habían sido igualitarios, además de ello, el aislamiento del campo se estaba rompiendo y el mercado, gradualmente, iba imponiendo cambios adaptativos a las sociedades rurales y alterando las viejas costumbres. El papel que le cupo al ferrocarril en ello, fue más bien discreto. Antes de la Guerra europea, de todos modos, se había conseguido coronar en 1905 la salida oriental hacia Santander, y se había abierto una nueva línea hacia el puerto de San Esteban de Pravia; algo más tarde se conectaba con un nuevo valle, en Aller, y finalmente se inauguraba otro tramo de Gijón a la localidad próxima de Candás (1909). La baratura de los billetes, en todo caso, hizo que en un sólo año, el de 1908, una de las compañías declarase haber trasladado 520.490 viajeros en sus líneas. Aunque fuese excepcionalmente, para ir a una romería o santuario de renombre, el ferrocarril conseguía tener una influencia creciente incluso en zonas relativamente aleja-

38 CARDESÍN DÍAZ, J. M.: «La crise de la vaine pâture au XIXe siècle: législation étatique et stratégies paysannes dans une paroisse de Galice (Espagne)», en Droit et Cultures, 1 (1981), pp. 1943; del mismo autor Tierra..., opus cit., pp. 210 y ss., y «Miseria de la teoría... de la modernización: Una revisión de algunos estudios sociológicos sobre el mundo rural contemporáneo», en Agricultura y sociedad, 84 (1997); DOMíNGUEZ MARTín, R.: «La evolución...», opus cit., pp. 903-905.

39 FERrería, José P.: Evolución civil y organización agraria de Asturias. Apuntes para la bistoria política del Principado, Rosario de Santa Fé (Argentina), 1914, p. 106, 179-181. ERICE, F.: Propietarios..., opus cit., pp. 53 y ss.; MORO BARREÑADA, J. M.: «Propietarios y colonos en Asturias en el siglo XIX. Notas en torno a la propiedad y uso de la tierra", en Astura, 1 (1983) pp. 49-54.

Hispania, LXII/3, núm. 212 (2002) 1059-1098 
das. La mejoría en las carreteras fue más importante; aunque entre 1900 y 1912 el trazado apenas se incrementó en 352 kilómetros, la red de caminos vecinales era buena en concejos como el de Oviedo y Piloña, y sobre todo, la construcción de algunos puentes, el mayor cuidado de las carreteras, y los avances en la técnica de construcción automovilística —un motor de explosión mas ligero, la adopción de los neumáticos- permitió una mayor generalización de los automóviles en las carreteras. Lo que a principios de siglo era una diversión para audaces deportistas, acabó siendo un medio de transporte de viajeros rápido y relativamente barato; en 1908 se inauguró la primera línea de viajeros por carretera, y antes de 1914 las diligencias perdían la batalla frente a los automóviles de línea ${ }^{40}$.

La inserción en el mercado de las economías campesinas había avanzado de manera ostensible para entonces. Las topografías médicas nos informan de una dieta en donde, poco a poco, y debido sin duda al desahogo creciente y a los mayores rendimientos de la explotación empezaba a destinarse al consumo diario lo que antes se orientaba al mercado local - la leche sin descremar, por ejemplo-; apareciendo también productos no indígenas en la alimentación cotidiana como el azúcar — y no la miel—, el vino - y no la sidra—, el chocolate, o el café. El consumo de fertilizantes, a su vez, avanzaba discretamente. Desde principios de siglo las azucareras habían estimulado el uso de abonos y maquinaria para obtener mayores rendimientos; paralelamente, en áreas como Navia y Luarca el consumo de fertilizantes se estimaba en 1905 en unas 1500 toneladas para una población en ambos concejos estimada en 30.486 habitantes en 1900; al parecer, la orientación ganadera también estaba perfectamente perfilada al igual que la introducción de especies forrajeras para el pasto, la estabulación permanente del ganado, e incluso cierta especialización agrícola; hacia 1914 los herreros de la zona ya sabían construir «máquinas agrícolas apropiadas a cada terreno sin necesidad de tener que traer los modelos del extranjero». En otras zonas la instauración de plantas para la industrialización de la leche como Mantequerías Arias (1910), o la discreta acción de instituciones oficiales a la hora de mejorar los hábitos higiénicos ganaderos, o de introducir nuevas razas de leche y de carne, tenían efectos similares en cuanto a la inserción del mundo agrario en el mercado. Las manufacturas locales se hundían frente a la competencia de las que trabajaban para un mercado nacional más amplio; el traje "típico» del país, que usaba de los tejidos tradicionales y que aún podía verse en algunos concejos a finales del siglo XIX, era ya una rareza en vísperas de la Primera guerra mundial. De hecho en 1904 dejó de sembrarse lino en el concejo de Caravia, y en Luarca poco antes de estallar la Guerra; en

40 Nava Valdés, A.: Turismo Asturias (Guía para el turista), Luarca, 1914, p. 138-150. GoNZÁLEZ VALDÉs, Fernando: Topografía médica del concejo de Oviedo, Madrid, 1911, p. 15 y 95; El perfil de Piloña...opus cit., p. 188-190. CASARIEGo, Jesús Evaristo: Caminos y viajeros..., opus cit., pp. 139143. El Carbayón, Oviedo, 8-VIII-1908.

Hispania, LXII/3, núm. 212 (2002) 1059-1098 
ese momento el traje de asturiano era ya un mero disfraz en los carnavales de esta última localidad ${ }^{41}$.

El sindicalismo agrario estimuló la difusión de todas estas novedades. En el período 1898-1914 se crearon al menos 248 de estas entidades; las de caracter laico tenían su sede en la villa cabecera del concejo y contaban, a veces, con secciones locales más pequeñas; las parroquias eran en cambio las sedes de las católicas; unas y otras habían formado potentes federaciones antes de 1914 de tipo laico (desde 1910) o católico (desde 1913). Su importancia como mecanismo de encuadramiento y de control social no puede minusvalorarse. La Sociedad Agrícola Gijonesa, por ejemplo, tenía 1400 afiliados en 1914, la de Pravia 1000, y la de Piloña 1600 por las mismas fechas. Las áreas mejor comunicadas y próximas a los núcleos urbanos consumidores o las de mayor densidad poblacional fueron su territorio preferente, y el seguro mutuo para el ganado, era uno de sus puntos más importantes; también podían dar premios a los mejores ejemplares de carne o leche, o a los sementales más adecuados, 0 crear o revitalizar puestos de venta, ferias o mercados para facilitar las transacciones. Sus cooperativas, a la vez, aseguraban el aprovisionamiento a precios asequibles, y proporcionaban aperos y herramientas agrícolas, abonos, o semillas seleccionadas. El impacto de estos servicios fue considerable; aumentó la seguridad en la posesión y beneficio de los ganados, y tecnificó las explotaciones. Sus gestores se encargaron, en algún caso como el de la sociedad de Piloña, de acopiar los excedentes agrícolas y distribuirlos para su venta en los mercados regionales o extraregionales, como en el caso de las producciones de manzana para sidra, o de avellana ${ }^{42}$.

$\mathrm{Al}$ igual que el mito del supuesto aislamiento de la comunidad campesina, tampoco la paz y la armonía resultaron valores firmes. La criminalidad y las manifestaciones de delincuencia, que hasta entonces parecían manifestaciones exclusivas de las zonas urbanas, hicieron acto de presencia en el campo. Su evidencia en uno de los emblemas de la sociedad apacible y amena del campo, las

41 GonZÁlez ValdÉs, F.: opus cit., pp. 95 y 103; Villalaín, José de: Topografía médica del concejo de Luarca, Madrid, 1915, pp. 62 y 75-80. CANALS, Salvador: Asturias..., opus cit., pp. XXIXXXX. QUiRós LiNARES, F.: «Notas sobre las fábricas azucareras en Asturias (1893-1957)», en Ería, Oviedo, 3 (1982). El Noroeste, Gijón, 15-III-1905. CrIADO, C. M. y PÉrEZ, R.: Notas sobre la dinámica y estructura de la población de Asturias (1875-1970), Oviedo, 1975, pp. 64-65. Muestras de los empeños oficiales por la introducción de nuevas razas ganaderas u otro tipo de mejoras puede verse, por ejemplo, en Río, G.: Cartilla del Labrador para la cría y Fomento de la Ganadería Asturiana, Oviedo, 1911; Reglamento especial para la Exposición Provincial (Oviedo, 1911), o en el Reglamento especial para la Exposición Provincial (Oviedo, 1902). Véase también, LLANO, Aurelio de: El libro de Caravia, Oviedo, 1919, p. 53

42 FERnÁndeZ, B. y GIRÓN, J.: «Aproximación al sindicalismo .....» opus cit.; URÍA, J.: Sociedad..., opus cit., pp. 659-799; datos de Piloña en El perfil..., opus cit. El proceso de arraigo del asociacionismo agrario en España es aún mal conocido; agradezco en todo caso el haber podido conocer un original de Juan PAN MONTOJO sobre esta temática («Las asociaciones rurales y el nacimiento del sindicalismo agrario en España 1834-1907») por gentileza de su autor.

Hispania, LXII/3, núm. 212 (2002) 1059-1098 
romerías, trastocó su imagen tradicional. A decir verdad, estas fiestas ya no eran exactamente el festejo despreocupado y desinhibido de la comunidad o de los mozos y mozas casaderos; las más afamadas congregaban a multitudes de hasta 10.000 personas y, sobre todo, estaban concebidas como una argucia de los comerciantes locales para atraer forasteros con capacidad de gasto. Habían entrado en una feroz competencia capitalista, y en una carrera de gastos donde los derroches de luz eléctrica, el cine o las canciones de cupletistas de moda dejaban poco espacio para la viejas danzas y canciones tradicionales. Las tensiones sociales hicieron aparición en las romerías criminalizando su protocolo; la paliza interparroquial, antaño estandarte de las diversiones patriarcales, y uno de los temas tradicionalmente acariciados por la literatura regional acabó degenerando en enfrentamientos de cierta importancia a pistola o navaja, armas desconocidas hasta entonces en las zonas rurales. La presencia de fuerzas de la Guardia Civil solicitadas por los alcaldes pedáneos para el sostenimiento del orden en los festejos, empezó a hacerse corriente desde al menos 1905. El término de paliza empezó a ser impropio para denominar estos enfrentamientos, y el periodismo de la época comenzó a utilizar otro más inquietante: el de batalla ${ }^{43}$.

La creciente complejidad de la vida económica campesina incrementó, en todo caso, los motivos para el conflicto. Uno de los más tempranos tuvo que ver con los trastornos abiertos por la producción azucarera. La sobreproducción detectada en 1900 y el reajuste consiguiente de los precios estimuló la organización campesina de «ligas", "cámaras» o "asambleas» en al menos seis concejos del centro asturiano. Su grado de coordinación, mínimo seguramente durante esta fase inicial, cuajó sin embargo en áreas como Gijón; en donde se formó una Asamblea de labradores en aquel año y se intentó coordinar el movimiento de oposición a las azucareras de otros lugares de Asturias. En pleno proceso de reestructuración y de cierre de plantas azucareras como las de Pravia (1903), Villalegre (1906) y Lieres (1908), prosiguió la movilización campesina boicoteando la firma de contratos con las plantas de Llanera (1904), y nuevamente Gijón (1910). En 1914, en fin, y con motivo de la reestructuración productiva y de precios abierta en ese año, los conflictos volvían a saltar en concejos como Pola de Siero, Lugones, Avilés, Gozón y, por supuesto, Gijón. En todo este proceso de protestas había sido perceptible el papel creciente que en su gestión habían tomado las. Asociaciones de agricultores y que se había coronado con la participación en el conflicto de la Federación de Agricultores Asturianos, de orientación laica y creada en $1911^{44}$. La comercialización de la

43 Una visión tradicional de la romería, de acuerdo con los patrones de la criminología de la época, en Aramburu, F. de: Monografía de Asturias, Oviedo, 1900, pp. 226-227.; o GIMENO DE AZCÁrate, M.: La criminalidad en Asturias, Oviedo, 1900, pp. 94-95. Un análisis del cambio en el protocolo de las romerías, en URíA, J.: «De la fiesta tradicional...» opus cit.

44 Datos sobre la actividad de las azucareras en QUIRÓs, F.: «Notas....", opus cit.; y ERICE, F. «Burguesía y desarrollo capitalista en la Asturias del siglo XIX», Oviedo, tesis doctoral, 1988, pp. 953-960. Un seguimiento a través de la prensa de los conflictos azucareros, y sobre todo a partir del

Hispania, LXII/3, núm. 212 (2002) 1059-1098 
sidra fue también causante de tensas situaciones; la responsabilidad de su producción recaía esencialmente en pequeños lagareros, afectados por un proyecto de tributación sobre los alcoholes contra el que se movilizaron a lo largo de los años 1906, 1907 y 1908. La Asociación de Gijón lideró nuevamente un movimiento en el que se involucraron otras sociedades regionales, y que desembocó en 1907 en una manifestación campesina de cierta importancia, coronándose en 1908 con la coordinación de las asociaciones agrícolas de la provincia con el fin de hacer más eficaz la protesta. Con todo, y pese a conseguirse una discreta suspensión de las consecuencias de la ley en Asturias, el problema legal subsistía; y un rumor desatado en 1911 activaba el movimiento opositor de los lagareros, otra vez, desde Gijón ${ }^{45}$. También la leche fue objeto de conflictos por los años anteriores a la Primera guerra mundial. La tipología de los incidentes casi siempre tenía el mismo aspecto, y arrancaba del intento de las autoridades locales de gravar su venta en las ciudades, con la consiguiente oposición de los pequeños abastecedores a satisfacerlo. De entre todos estos conflictos iba a destacarse sin embargo uno debido a su duración, sus implicaciones populares y sus graves derivaciones de orden público: la «guerra de la leche» gijonesa de 1909. El conflicto no es la primera vez que ha sido contado. La profesora P. Radcliff, de hecho, ha ofrecido una explicación solvente del papel que la huelga tuvo en la dinámica de movilización popular y radicalización que vivió la ciudad desde entonces. A nuestros efectos, sin embargo, nos interesa contemplar el conflicto más bien como resultado de una problemática específica del campesinado, que ya había conocido otros episodios similares de tensión por idénticas causas, y en la misma zona y fuera de ella; y que salpicó en su desarrollo a concejos limítrofes como Carreño y Villaviciosa, rebasando en principio el radio de acción estricto del concejo y de la propia Asociación de Labradores gijonesa. En realidad, los campesinos de muchas otras partes de Asturias participaban también del movimiento de hostilidad contra las tasas municipales - los odiados consumos - que gravaban muchos otros productos aparte de la leche, y que habían dado origen a distintos alborotos, manifestaciones en su contra, y apedreamientos de casetas de consumos ${ }^{46}$. La propiedad de la tierra, en fin, fue también motivo para algunos conflictos conducidos esencialmente, como los anteriores, por las sociedades de agricultores de carácter progresista y laico. Entre los años 1908 y 1910, por ejemplo, se localizaron algunas protestas contra los foros, conducidas desde las asociaciones agrícolas de Muros, Gijón, Cudillero, Mieres, Grado, Pravia, Ribadesella, Piloña y Llanera, que desembocaron en la convocatoria en el año 1908 de una Asamblea Antiforista, y en el sostenimiento de contactos con similares movimientos de las provincias vecinas

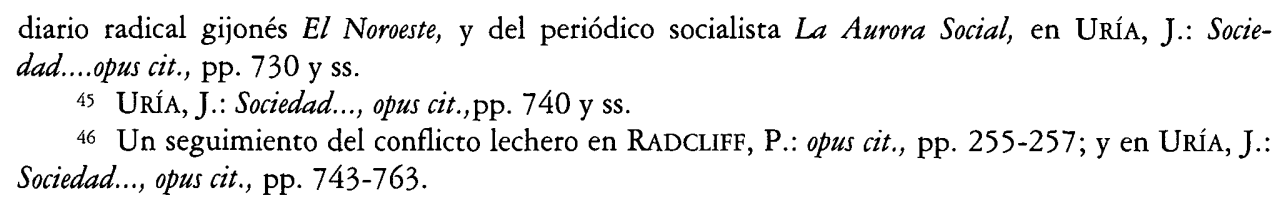


de Galicia y de León. Los nexos del movimiento con el Partido Reformista, en todo caso, acabaron favoreciendo el intento de una salida parlamentaria al problema, acarreando esta vía la gradual desmovilización campesina. No se trató, de todos modos, de los únicos casos de conflictos de este tipo; las agitaciones en comarcas como la de Grado antes de 1914 en contra de terratenientes como el Conde de Agüera o la Marquesa de Fonclara, o los desórdenes provocados en Villayón en 1908 a propósito de la renovación de los arriendos de los colonos del Marqués de Santa Cruz de Marcenado, lo prueban sobradamente ${ }^{47}$.

El funcionamiento real de la "comunidad campesina», por tanto, parecía distar bastante de los ideales armonicistas de Palacio Valdés; lo que es más, en rigor y como sabemos, no había funcionado así nunca. Su carácter de construcción mítica en todo caso no sólo se limitaba al capítulo de la conflictividad ni a épocas más o menos remotas en el tiempo, sino que tampoco se adaptó a los estándares esperados una vez que su inserción en el mercado fue un hecho. Los avances en la mercantilización, la pérdida de empuje de las regulaciones comunales de la tierra, el progreso cada vez más firme de los derechos individuales sobre los usos y gestión de la tierra, no desembocaron de este modo en un individualismo feroz y excluyente por parte de las sociedades campesinas, como cabría imaginar dentro de los paradigmas clásicos de la modernización. La comunidad local siguió siendo vigorosa, y no sólo por el hecho de que perviviese, según sabemos, la costumbre de la organización colectiva de los cultivos en las aldeas. Ésta, como otras costumbres colectivas, estaban en receso; pero su mantenimiento dependía estrictamente de la utilidad que tuviese para el campesino, estuviese o no en un avanzado estado de inserción en los mecanismos capitalistas del mercado. Como en otras zonas del norte de España, si en el pasado la gestión comunal de la tierra y las formas de apoyo comunitario habían garantizado la viabilidad de una explotación agraria en precario, ahora la comunidad podía sancionar la disolución de la organización colectiva de la tierra si le convenía, o por el contrario, como sucedía en 1914 en ciertos concejos, sostener la costumbre de reunir la junta del pueblo con el fin de regular la subida a los puertos de montaña para su explotación ganadera en el verano, a cargo de un pastor común de todo el vecindario. Eso acaecía en concejos como Allande, Ibias, Cangas de Narcea, Somiedo o Los Oscos, y no parecía fácil otra alternativa si se quería explotar racionalmente unos puertos de montaña impracticables durante el invierno. Por la misma época el mercado o fuerzas externas a la propia comunidad local no siempre eran las responsables de forzar inexorablemente la ruptura de los usos comunales y el avance de la explotación individual. Por el contrario, decisiones que también emanaban de los propios campesinos podían explicar la persistencia de los viejos usos como una estrategia adaptativa de los más pobres para hacer viable su menguada explotación. Hacia 1914, y en parte debido a la «oposición y protesta» de los vecinos menos

47 Uría, J.: Sociedad..., opus cit., pp. 763 y ss. 
acomodados, aún se sostenían los rígidos ordenamientos de los repartos del terreno comunal indiviso, y la regulación estrictamente colectiva de los cultivos y de los usos ganaderos de ese espacio en algunas aldeas de San Martín de Oscos o Cangas de Narcea. La comunidad local, por lo demás, seguía siendo una unidad de gestión campesina que se superponía o funcionaba paralelamente al desenvolvimiento de esquemas organizativos aparentemente más modernos, como en el caso de las organizaciones sindicales de base local. No por casualidad, la tendencia en cuanto al encuadramiento de las comunidades locales a un sindicato agrario era la de la adscripción prácticamente en bloque de la aldea o la parroquia a una sóla de las opciones, fuese esta laica o católica, no siendo fácil que en un mismo pueblo coexistiesen dos organizaciones sindicales distintas que escindiesen los viejos ejes de solidaridad de base local. Las polémicas entre clericales y anticlericales, aunque sabemos que afectaron a las zonas rurales, no parecen haber amenazado la trabazón social de la aldea. En lugares como Piloña, por lo demás, las sucursales de parroquia del sindicato laico dominante en el concejo no interferían el funcionamiento de las asambleas de vecinos, que seguían organizando los servicios públicos de la localidad e incluso regulando el orden público y una rudimentaria sistematización judicial para los vecinos ${ }^{48}$.

En contra de lo esperado, asimismo, el funcionamiento político caciquil, que en teoría derramaba de arriba a abajo sus decisiones, quedaba desmentido en la práctica por algunos comportamientos campesinos que, otra vez, les devolvían protagonismo como grupo social mostrando un papel indudablemente activo de la comunidad local. Frente a los intentos de control caciquil de políticos dinásticos o reformistas, en los años inmediatamente anteriores a la Guerra mundial, y habiéndose presentado una elección al parlamento reñida, los vecinos forzaron una negociación en donde se pretendía cambiar el voto por determinados servicios públicos. Sucedía esto en la Braña de Pena, en el concejo de Luarca, donde tras reunirse los vecinos en asamblea y deliberar sobre el caso, nombraron una comisión para negociar con el cacique de los liberales, prometiéndole el voto a cambio de la construcción de un camino; al parecer, «el cacique de los liberales les prometió hasta un ferrocarril, pero los vaqueiros se conformaron con el camino, exigiendo, eso sí, que el cacique tenía que depositar previamente tres mil y pico de pesetas como garantía, hasta pasado medio año, en las manos de la persona que ellos designaran al efecto». Las vaguedades con las que les respondió el miembro del partido liberal, incitaron a los campesinos a negociar con el partido conservador con quien cerraron la operación; «votaron el día de la elección todos a una por el tal candidato y antes del medio año el camino estaba hecho». A las siguientes elecciones, en cambio, y cuando el candidato conservador se creía más seguro, los lugareños abrieron una nueva negociación para forzar la construcción de una escuela; y mediante las tres mil

48 FERrería, J. P.: opus cit., pp. 148-149; El perfil..., opus cit., pp. 235-236.

Hispania, LXII/3, núm. 212 (2002) 1059-1098 
pesetas de depósito, fue el candidato liberal el que se llevó los votos cumpliendo estrictamente con su promesa ${ }^{49}$.

Los campesinos, por tanto, mostraron poseer una cultura comunitaria que, al margen por completo de los modelos de la "comunidad campesina", daba muestras de gozar de una buena salud todavía. En esto, Palacio Valdés también se había equivocado. Los penachos humeantes de las fábricas es posible que hubiesen desgarrado el «seno virginal» y profanado la «belleza inmaculada» de una comunidad que, en rigor, nunca había existido. Pero, a la postre, habían socavado menos de lo esperado lo esencial de sus viejas capacidades adaptativas $o$, a la inversa, de sus actitudes de resistencia ante los cambios que más podían perjudicarla ${ }^{50}$.

49 Ferrería, J. P.: opus cit., pp. 107-109.

so Palacio Valdés, A.: La aldea perdida, opus cit., p.9.

Hispania, LXII/3, núm. 212 (2002) 1059-1098 